Boston University School of Law

Scholarly Commons at Boston University School of Law

Faculty Scholarship

$1-1-2012$

\title{
Cost-Benefit Federalism: Reconciling Collective Action Federalism and Libertarian Federalism in the Obamacare Litigation and Beyond
}

\author{
Abigail Moncrieff \\ Boston Univeristy School of Law
}

Follow this and additional works at: https://scholarship.law.bu.edu/faculty_scholarship

Part of the Health Law and Policy Commons

\section{Recommended Citation}

Abigail Moncrieff, Cost-Benefit Federalism: Reconciling Collective Action Federalism and Libertarian Federalism in the Obamacare Litigation and Beyond, in 38 American Journal of Law \& Medicine 288 (2012).

Available at: https://scholarship.law.bu.edu/faculty_scholarship/245

This Article is brought to you for free and open access by Scholarly Commons at Boston University School of Law. It has been accepted for inclusion in Faculty Scholarship by an authorized administrator of Scholarly Commons at Boston University School of Law. For more information, please contact lawlessa@bu.edu. 


\title{
BU School of Law
}

\section{Cost-Benefit Federalism: ReConCILING COLLECTIVE ACTION FEDERALISM AND LIBERTARIAN FEDERALISM IN THE OBAMACARE LITIGATION AND BEYOND}

American Journal of Law \& Medicine, Vol. 37, p. 288, 2012

Boston University School of Law, Law \& Economics Paper No. 12-33

(June 22, 2012)

Boston University School of Law, Public Law \& Legal Theory Paper No. 12-33

(June 22, 2012)

\author{
Abigail R. Moncrieff \\ Boston University School of Law
}

This paper can be downloaded without charge at:

http://www.bu.edu/law/faculty/scholarship/workingpapers/2012.html 


\title{
Cost-Benefit Federalism: Reconciling Collective Action Federalism and Libertarian Federalism in the Obamacare Litigation and Beyond
}

\author{
Abigail R. Moncrieff ${ }^{\dagger}$
}

\section{INTRODUCTION}

The lawsuits challenging Obamacare's ${ }^{1}$ individual mandate ${ }^{2}$ have exposed a rift in federalism theory. On one side of the divide is a view that the national government ought to intervene-and ought to be constitutionally permitted to intervene-whenever the states are "separately incompetent" to regulate a particular subject. ${ }^{4}$ According to this view, the primary purpose of the Constitution's enumeration of national powers is to authorize Congress to fix collective action problems among the states. ${ }^{5}$ Borrowing from Robert Cooter and Neil Siegel's article of the same name, I refer to this view as "collective action federalism." ${ }^{6}$ On the other

\footnotetext{
${ }^{\dagger}$ Peter Paul Career Development Professor and Associate Professor of Law, Boston University School of Law.

${ }^{1}$ See Patient Protection and Affordable Care Act, Pub. L. No. 111-148, 124 Stat. 119 (2010), amended by Health Care and Education Reconciliation Act of 2010, Pub. L. No. 111-152, 124 Stat. 1029 (to be codified primarily in scattered sections of 42 U.S.C.) [hereinafter ACA]. The moniker "Obamacare" is one that has been associated with the law's opponents, but I like the name better than "PPACA" or "ACA" and will therefore use it despite arguing for the statute's constitutionality.

${ }^{2}$ See ACA $\S 1501$ (codified as amended at 26 U.S.C.A. § 5000A (West 2012)).

${ }^{3}$ See Robert Cooter \& Neil S. Siegel, Collective Action Federalism: A General Theory of Article I, Section 8, 63 Stan. L. Rev. 115, 117 (2010) (quoting 2 The Records of the Federal CONVENTION OF 1787, at 131-32 (Max Farrand ed., rev. ed. 1966)).

${ }^{4}$ See, e.g., Jack Balkin, Commerce, 109 Mich. L. Rev. 1, $46-47$ (2010); Patrick McKinley Brennan, The Individual Mandate, Sovereignty, and the Ends of Good Government: A Reply to Professor Barnett, 159 U. PA. L. REv. 1623 (2011); Mark A. Hall, Commerce Clause Challenges to Health Care Reform, 159 U. PA. L. Rev. 1825 (2011); Andrew Koppelman, Bad News for Mail Robbers: The Obvious Constitutionality of Health Care Reform, 121 YALE L.J. OnLINE 1 (2011), http://yalelawjournal.org/2011/04/26/koppelman.html; Neil S. Siegel, Free Riding on Benevolence: Collective Action Federalism and the Individual Mandate, 75 LAW \& CONTEMP. PROBS. (forthcoming 2012); Peter J. Smith, Federalism, Lochner, and the Individual Mandate, 91 B.U. L. REV. 1723 (2011). See generally Sam Singer, Defending the Affordable Care Act: What the Justice Department Can Learn from the Legal Academy, VA. REV., http://www.vareview.com/ContributorArticles/ Articles/AboutTheHealthCareLawsuits.aspx (last visited Feb. 21, 2012) (noting that most members of the legal academy seem to be following a collective action theory of federalism in their defenses of Obamacare)

${ }^{5}$ See Cooter \& Siegel, supra note 3.

${ }^{6} \mathrm{Id}$.
} 
side of the divide is a view that federalism exists for reasons other than efficiency of regulation and particularly that the Founders created the federal structure for the protection of individual liberty. ${ }^{7}$ According to this view, there is inherent value to state power that ought to be preserved against national encroachments. ${ }^{8}$ I refer to this view as "libertarian federalism." In the Obamacare litigation, believers in collective action federalism generally support the individual mandate while believers in libertarian federalism generally oppose it. ${ }^{9}$

This Article presents a standard cost-benefit theory to bridge the gap-to reconcile the two competing theories of federalism. The cost-benefit theory is premised on two basic views. First, federalism exists both to promote regulatory efficiency and to protect individual liberty. That is, collective action federalism and libertarian federalism both rest on sound foundations. Second, regulatory efficiency always counsels in favor of national authority while individual liberty always counsels in favor of state authority. Either collective action federalism or libertarian federalism, if followed to its natural conclusion, would do away with federalism altogether. Assuming, then, that federalism is worth preserving and that both views rest on good foundations, the Supreme Court ought not to adopt one view to the exclusion of the other.

Fortunately, it is quite possible to follow both views simultaneously by optimizing the balance between the two. Under cost-benefit federalism, the inquiry ought to weigh the efficiency losses of state action against the liberty losses of national action and ought to choose the approach that maximizes the value- the benefits minus the costs - in the distribution of governmental authority. That is, if the libertarian costs of federalization outweigh its efficiency benefits, then Congress ought to leave regulation to the states. But if the efficiency benefits outweigh the libertarian costs, then Congress ought to regulate. Unlike the collective action and libertarian theories, the cost-benefit approach allows for some generalizable distinctions in the kinds of regimes that should fall to Congress and the kinds that should fall to the states. Cost-benefit federalism does not argue monotonically for national or state control. Indeed, the cost-benefit theory suggests a federalism line that roughly tracks the current doctrinal distinction: the economic/noneconomic distinction in the Supreme Court's Commerce Clause cases. ${ }^{10}$

That said, the simple account of the cost-benefit theory is too simple, for two reasons. First, not all regulation is monopolistically state or national; many

\footnotetext{
${ }^{7}$ See The Federalist No. 51 (James Madison).

${ }^{8}$ See, e.g., Randy E. Barnett, Commandeering the People: Why the Individual Health Insurance Mandate Is Unconstitutional, 5 N.Y.U. J.L. \& LIBERTY 581 (2010) [hereinafter Balkin, Commandeering the People]; Randy E. Barnett, Jack Balkin's Interaction Theory of Commerce, 2012 U. ILL. L. REv. (forthcoming 2012); Gary Lawson \& David B. Kopel, Bad News for Professor Koppelman: The Incidental Unconstitutionality of the Individual Mandate, 121 YALE L.J. ONLINE 267 (2011), http://yalelawjournal.org/2011/11/08/lawson\&kopel.html; Ilya Somin, Taking Stock of Comstock: The Necessary and Proper Clause and the Limits of Federal Power, 2010 CATO SUP. CT. REv. 239; Kurt T. Lash, "Resolution VI": National Authority to Resolve Collective Action Problems Under Article I, Section 8 (Ill. Pub. Law \& Legal Theory, Research Paper No. 10-40, 2012), available at http://papers.ssrn.com/sol3/ papers.cfm?abstract_id=1894737.

${ }^{9}$ Compare Cooter \& Siegel, supra note 3, at 185 n.243, with Barnett, Commandeering the People, supra note 8, at 582-83.

${ }^{10}$ See generally Cooter \& Siegel, supra note 3, at 131-34 (tracing the economic/noneconomic distinction in the precedent); Roderick M. Hills, Jr., The Individual Right to Federalism in the Rehnquist Court, 74 GEO. WASH. L. REV. 888 (2006) (describing the same distinction and comparing it to the distinction for individual substantive rights, which is also generally an economic/noneconomic distinction).
} 
regulatory regimes involve both levels of government. ${ }^{11}$ But while national action can preserve state advantages, state action has a much harder time capturing national advantages. ${ }^{12}$ Congress can (and frequently does) write national legislation that preserves states' ability to protect individual liberty (through either "cooperative federalism" programs or narrowly preemptive national laws), but states rarely surmount their collective action problems to engage in more-efficient coordinated efforts. ${ }^{13}$ It might be quite rational, therefore, for courts and commentators to take a less skeptical view of national claims to action than of state claims to action. Second, the notion that the best approach to constitutional federalism would optimize the balance between regulatory efficiency and individual liberty elides an institutional competence problem. The courts are not institutionally capable of calculating and enforcing the optimal federalist balance, but neither is Congress. Information about the costs and benefits of regulation simply is unavailable. Optimality is thus a theoretical first-best answer to federalism rather than a judicially or legislatively administrable test. Nevertheless, the legislature's greater democratic legitimacy gives it a constitutionally relevant claim to supremacy on the federalism question. Congress is structurally better suited than the courts to gather the information that is available and to make legitimate decisions based on that information. The courts therefore should and do defer to Congress's rational decisions. ${ }^{14}$ As long as Congress has not chosen a federalist balance that skews to an extreme of efficiency at the cost of liberty (and the states have not asserted a power that skews to an extreme of liberty at the cost of efficiency), the courts should not intervene.

What about Obamacare? Under the cost-benefit approach I outline here, the theoretical test for Obamacare's federalism is whether the libertarian costs of increasing the national government's control over individual health insurance purchases will outweigh the efficiency costs of the status quo ante's level of state control. Notably, that question is more complicated than the litigants and the courts have made it seem. The analysis ought to incorporate a fuller understanding of the balance that Congress actually struck in the statute as well as a fuller understanding of the balance that existed before Obamacare's passage. We ought not to pretend, as many of the litigants and commentators have,${ }^{15}$ that Obamacare represents a full national takeover of health insurance regulation or that the pre-Obamacare world was one of full state control. Of course, even with that more nuanced understanding, it will be impossible to give any precise estimate to Obamacare's true federalist

${ }^{11}$ See generally Roderick M. Hills, Jr., The Political Economy of Cooperative Federalism: Why State Autonomy Makes Sense and "Dual Sovereignty" Doesn't, 96 Mich. L. REV. 813 (1998) (discussing the phenomenon of cooperative federalism programs and the political economy of intergovernmental relations within those programs).

${ }^{12}$ See Malcolm M. Feeley \& Edward Rubin, Federalism: Political Identity and Tragic COMPROMISE (2008) (noting that federalism and decentralization ought to be treated as separate concepts and that national authority need not imply full centralization of decision-making); Abigail R. Moncrieff \& Eric Lee, The Positive Case for Centralization in Health Care Regulation: The Federalism Failures of the ACA, 20 KAN. J.L. \& PUB. POL'Y 266, 278-79 (2011) (noting that Medicare captures many advantages of state control by running policy experiments and decentralizing authority to local fiscal intermediaries).

${ }^{13}$ See Hills, supra note 11 , at $858-71$.

${ }^{14}$ See United States v. Lopez, 514 U.S. 549, 557 (1995) (stating a "rational basis" test for review of national regulations defended under the Commerce Clause).

15 See OBAmaCARe: MANDATORY SOCIAlized Medicine, http://www.akdart.com obama184.html (last visited Feb. 21, 2012) (webpage containing many links to commentaries about Obamacare) 
value. Both the statute's efficiency gains and its liberty costs are impossible to calculate because so many of the costs and benefits are insusceptible to standardized measurement. In practice, then, the question of Obamacare's federalism ought to be whether the balance that Congress struck between efficiency and liberty is irrational. If not, then the law ought to be upheld.

This Article argues that most commentators have exaggerated all three of the relevant issues with Obamacare: its efficiency gains, its liberty costs, and its departure from the status quo ante's federalist balance. The collective action problem with state insurance regulation is not as bad as scholars of collective action federalism have argued; the liberty implications of the individual mandate are not as extreme as scholars of libertarian federalism have argued; and the shift from state to national power is not as significant as the litigants and courts have argued. Although I do not make the strong claim that Obamacare reaches the optimal balance between regulatory efficiency and individual liberty, I do make the weaker doctrinal claim that Obamacare strikes an eminently rational federalist balance, which deserves judicial deference.

This Article proceeds as follows. Part II makes the case that both collective action federalism and libertarian federalism rest on sound foundations but that either theory taken alone would argue against federalism - in favor of either full national or full state authority. That Part then argues that the first-best theory of federalism would seek the optimal balance between these competing visions. Part II fleshes out the two complicating factors in the simple version of cost-benefit federalism: the frequent hybrid state-national strategies that Congress pursues and the impossibility of discovering optimality with precision. Part III then makes the case for judicial deference to Congress's federalism. Part IV turns to Obamacare and argues that the literature and the litigation alike have exaggerated the statute's relevant federalism implications, including its efficiency gains, its liberty costs, and its departure from the status quo ante. Part IV also argues that Obamacare strikes a rational balance between state and national power that ought to be preserved.

\section{COST-BENEFIT FEDERALISM}

Throughout the Obamacare litigation, two competing visions of federalism have vied for supremacy. According to collective action federalism, Congress should be empowered to address any problem that the states are separately incompetent to address. ${ }^{16}$ If a regulatory regime suffers from interstate externalities (like adverse selection and cost-shifting in health insurance markets, according to the advocates of this theory), then Congress should be allowed to intervene. ${ }^{17}$ Under the competing vision of federalism, libertarian federalism, the states should retain primary regulatory authority because state power better preserves individual liberty. ${ }^{18}$ Especially if a regulatory regime imposes on individual autonomy in some new or troubling way (as does Obamacare's individual mandate, according to the advocates of this theory), each state should remain free to reject the imposition. Although both of these visions of federalism rest on legitimate theoretical foundations, each vision taken alone would argue for the end of federalism. Collective action federalism argues monotonically for national control while libertarian federalism argues monotonically for state control. In order to capture the foundational correctness of

\footnotetext{
${ }^{16}$ See Lash, supra note 8, at 2-3.

${ }^{17}$ See Koppelman, supra note 4, at 12-13.

${ }^{18}$ See Hills, supra note 10 , at 904.
} 
both views, federalism doctrine ought to seek a balance between the two visionsbetween the efficiency of national regulation and the liberty of state regulation.

This Part will demonstrate that the national government is better situated, from a purely structural perspective, to capture regulatory efficiency while the state governments are better situated, from the same purely structural perspective, to preserve individual liberty - and that these structural capacities apply to every regulatory regime. It will then make the case that efficiency and liberty should serve as mutual constraints for one another and that the goal of a federal (rather than either a purely central or a purely diffuse) system of government should be to optimize the balance between the two values.

\section{A. COLLECTIVE ACTION FEDERALISM}

According to collective action federalism, Congress should be empowered to address any regulatory problem that the states are "separately incompetent" to solve. ${ }^{19}$ In elaborating this general theory of national power, Cooter and Siegel articulate an "internalization principle" ${ }^{, 20}$ for determining which level of government should be authorized to address a problem. In their view, the Constitution should "assign power to the smallest unit of government that internalizes the effects of its exercise." 21 As we shall see, however, the scope of that principle depends on whether Cooter and Siegel mean "the smallest unit of government that internalizes most of the effects of its exercise" or "the smallest unit of government that internalizes all of the effects of its exercise." If they intend the former (as they seem to), then we need a theory for what constitutes most. How significant does an interstate externality need to be before Congress may constitutionally intervene? Cooter and Siegel provide no answer. If they intend the latter (which they seem not to), then the theory argues for nationalization of all social and economic policy. All such policy suffers from some interstate externalization because the citizenry is freely mobile.

I will describe and model the problem of interstate externalities (the collective action problem that defines collective action federalism) and will explain why the theory needs some kind of limiting principle in order to be a theory of federalism rather than a theory of nationalism. I will also provide two possible empirical limits for the theory, both of which I find legally unsatisfying.

\section{Interstate Externalities}

The core problem that collective action federalism seeks to address is the problem of regulatory spillovers between and among the states. To see this problem in action, I will use the canonical example of interstate externalities that justify national intervention: pollution. If Massachusetts, for example, undersupplies pollution abatement, some of the effects of that choice will travel to other states because some of the excess pollution will travel downstream to New Hampshire or Rhode Island (and beyond). Acting alone, therefore, Massachusetts's incentive to punish polluters is incomplete.

\footnotetext{
${ }^{19}$ See Lash, supra note 8, at 2-3.

${ }^{20}$ Cooter \& Siegel, supra note 3, at 137.

${ }^{21} \mathrm{Id}$.
} 
We can express the problem with a simple model. ${ }^{22}$ Ideally, a government will regulate up to the point that the social benefits of the regulation (cleaner air and water) equal the social costs of the regulation (enactment and enforcement costs as well as lost economic productivity from pollution reductions). The constraint, then, is that a regulation should pass whenever:

$$
S B_{r} \geq S C_{r}
$$

If some of the regulation's benefits (some of the cleaner air and water) will travel to a different governmental system (a neighboring state), then voters and legislators will rationally spend less than the optimal amount of social cost (like time, effort, money, opportunity cost, and political capital) on regulating. The social benefit that they can expect to capture from the regulation will be less than the full social benefit that the regulation produces. The externalized benefits affect the rational regulatory constraint as follows, where $e_{l}$ is the externalized social benefit of regulating:

$$
S B_{r}-e_{1} \geq S C_{r}
$$

When this kind of externality occurs, each state acting alone systematically underproduces socially valuable regulation.

Furthermore, the social costs of regulating might also increase due to interstate externalities. Imagine, for example, that Massachusetts imposes strict pollution controls on its industrial manufacturers while New Hampshire chooses a laxer regulatory environment. The regulated entities will move from Massachusetts to New Hampshire in order to avoid the higher cost of complying with Massachusetts's pollution abatement laws, causing Massachusetts to suffer an additional social cost of regulating: lost jobs and tax revenues. Massachusetts, then, has an incentive to regulate only until:

$$
\begin{gathered}
S B_{r}-e_{1} \geq S C_{r}+e_{2} \\
\text { or } \\
S B_{r}-e_{1}-e_{2} \geq S C_{r}
\end{gathered}
$$

We can think of the $e_{2}$ as a standard first-mover problem or multilateral prisoners' dilemma, where each state wants to avoid being the first actor to impose pollution abatement regulations because the first-acting state will lose business to later-acting states.

To put the constraint in slightly different terms, a state's willingness to pay for a regulation should equal the total social benefit that the regulation will produce (WTP $\left.=S B_{r}\right)$. Externalities cause the state to experience something less than the full social benefit, decreasing the state's willingness to pay accordingly $\left(W T P=S B_{r}-e_{1}-e_{2}-\right.$

${ }^{22}$ Throughout this Article, I will apply a rational actor model to regulatory decision-making. The rationality I apply here, however, is the tautological kind of rationality. If a government chooses to regulate, I assume that the benefits of the regulation outweigh the costs from the relevant government's perspective. Many lawmakers might include disfavored interests in the cost-benefit calculus, such as the lawmakers' personal pecuniary interests, and many lawmakers might suffer cognitive distortions in their assessments of costs and benefits, such as hyperbolic discounting. Those kinds of distortions undoubtedly are problematic insofar as they lead lawmakers to enact non-optimal regulations. None of that, though, undercuts the point I make here, which is just that externalization of costs and benefits to other governments is also a problem that likewise leads lawmakers to enact nonoptimal regulations. This point does not at all depend on the objective rationality of the lawmaker, though it does depend on a tautological assumption that lawmakers will not enact a regulation that, from their perspective, has higher costs than benefits. 
$\left.e_{3} \ldots-e_{n}\right)$. Externalization therefore pushes states systematically towards underproduction of regulation. ${ }^{23}$

To make this picture more concrete, imagine that the total social benefit Massachusetts could produce through pollution abatement laws is 100 utils. $^{24}$ In other words, imagine that polluters in Massachusetts are producing 100 utils worth of harm that could be reduced through regulatory intervention. Ideally, the people of Massachusetts would be willing to spend up to 100 utils of their own regulatory inputs to address the problem and reduce the harm. That is, Massachusetts should be willing to pass any pollution abatement law that is likely to be effective and that has a total social cost of 100 utils or less to enact and enforce.

Unfortunately, there are two externalization problems that will lead Massachusetts, quite rationally, to set its willingness to pay at less than 100 utils. First, some of the harm from pollution produced in Massachusetts occurs in other states, such that Massachusetts cannot expect to capture the full 100-util benefit of eliminating the pollution produced within its borders. Some of that benefit will accrue in the states to which Massachusetts's air and water travel. Imagine, then, that the out-of-state portion of the pollution abatement law's benefits- the $e_{1}$ of this scenario - is twenty-five utils. (In other words, imagine that twenty-five percent of the pollution generated in Massachusetts travels to and harms other states, such that twenty-five percent of the benefits from eliminating that pollution will accrue in other states.) That externality reduces Massachusetts's willingness to pay for regulation from 100 to seventy-five. The state therefore has a less-than-optimal incentive to produce pollution abatement laws.

Second, individuals' and corporations' freedom of travel among the states might heighten Massachusetts's social cost of enactment, particularly if its close neighbors refuse to regulate polluters. Imagine, then, that the cost to Massachusetts in industrial business lost to competing states-the $e_{2}$ in this scenario-is ten utils. That externality alone would reduce Massachusetts's willingness to pay for a 100util reduction in pollution to ninety utils, or if combined with the imagined $e_{1}$, it would reduce the willingness to pay to sixty-five utils. The $e_{2}$ therefore also decreases Massachusetts's incentive to produce pollution abatement laws, causing it to fall below the social optimum.

In short, the externalization of regulatory costs and benefits from one state to the next distorts the states' incentives to regulate. In the case of pollution abatement and in any other regime in which $e_{1}$ and $e_{2}$ both have positive value, each state is underincentivized to regulate relative to the social optimum. ${ }^{25}$

What about Congress's incentives? Assuming that the costs associated with both $e_{1}$ and $e_{2}$ are entirely internal to the United States, Congress's willingness to pay for the same pollution abatement in Massachusetts will be the full 100 utils. Congress captures all of the benefits to every state in the union of reducing pollution that

${ }^{23}$ It is possible that externalities can be positive from the regulating state's perspective, in which case externalization will push states to over-regulate rather than under-regulate. That is not the relevant case for Obamacare, however, and I therefore will not address that case here.

${ }^{24}$ I use the "util" (a hypothetical unit common in the economics literature to measure overall utility) as the unit of measurement for lack of any other unit that can capture the many varied costs and benefits of regulation, including those like happiness or sadness that are not subject to monetization. The util also permits the fiction that we can measure utility interpersonally, which is a fiction that I indulge for the stylized analysis here.

${ }^{25}$ As I mentioned in note 23, supra, there are cases in which $e_{1}$ or $e_{2}$ is negative, causing the states to over-regulate relative to optimum, but because that is not the relevant case for Obamacare and the individual mandate, I do not address that phenomenon here. 
originates in Massachusetts, and congressional policy-making can avoid the firstmover problem by setting a policy for all states at one time. In other words, assuming that all benefits and costs of regulating pollution in Massachusetts are internal to the United States, national decision-making will not be distorted; $e_{1}$ and $e_{2}$ will be zero, and the regulatory incentive will be optimal.

Of course, the assumption is false, at least with respect to pollution. In this regime, both $e_{1}$ and $e_{2}$ have international as well as interstate implications, meaning that Congress will suffer non-zero externalities just as Massachusetts would. With respect to $e_{1}$, some of the pollution produced in Massachusetts will travel to Canada, and some of it will contribute to global environmental degradations like climate change. With respect to $e_{2}$, national pollution restrictions might cause some manufacturers to set up shop overseas in less-restrictive developing nations like China, increasing the social cost to the United States of regulating polluters today relative to the cost that later-moving nations will experience from the same regulations.

Nevertheless, both of the externalities will be less impactful on the central government's willingness to pay than on the state governments' willingness to pay. As for $e_{1}$, the magnitude of the externality relative to the total social benefit will be smaller. This point is quite easy to see in the hypothetical case: a higher percentage of the pollution produced in Massachusetts will stay in the United States than will stay in Massachusetts. If the $e_{1}$ for Massachusetts is twenty-five utils, then the $e_{1}$ for Congress must be less than twenty-five utils because not all of the externalized harm from Massachusetts's pollution will reach Canada. Some of it will impact New Hampshire and Maine on its way to Canada, and some of it will go south instead, impacting Rhode Island and the states below. In the abstract, this point is mathematically true for all regulatory regimes imaginable. Simply by virtue of its size, the United States government must internalize a higher percentage of the harms it produces than any state government. As a ratio of its total geographic area, Massachusetts has more borderland than the United States, providing more opportunities for harms to sneak out of the territory. ${ }^{26}$ That is, a harm produced in the dead center of Massachusetts has to travel less distance to reach another state than a harm produced in the dead center of the United States has to travel to reach another nation, and a harm produced at any random point in Massachusetts has to travel a smaller average distance to reach another state than a harm produced at any random point in the United States has to travel, on average, to reach another nation. It is therefore mathematically certain that a larger government will internalize a higher percentage of the physical harms it produces than a smaller government, regardless of how many governments exist globally.

With respect to $e_{2}$, the point is equally easy to see within the constraints of the hypothetical, and the same mathematical certainty applies in the abstract, at least within the constraint of a finite global system (i.e., within the constraint that the land available for drawing jurisdictions is not infinite and is zero-sum). First take the hypothetical: if Massachusetts regulates in a way that its manufacturers dislike, the

\footnotetext{
${ }^{26}$ It is always mathematically true that the ratio of perimeter to area for any shape decreases as the shape grows. Perimeter grows linearly with size while area grows exponentially. For example, a circle's perimeter to area ratio is $2 \pi r: \pi r^{2}$. As the radius of the circle $(r)$ grows, $2 \pi r$ increases linearly, but $\pi r^{2}$ increases exponentially. The ratio between the two therefore decreases. The same is true for a square with a side of length $x$, for which the ratio of perimeter to area is $2 x: x^{2}$, and the same is true for any complex geometric shape. The math is more complicated for shapes in fractal dimensions, like coastlines, but the principle is the same.
} 
manufacturers are free to move to any other state in the country or to any other country in the world. ${ }^{27}$ They have many opportunities to escape the costly regulation when a smaller government acts. If Congress regulates in a way that the manufacturers dislike, however, they have forty-nine fewer options available for escape. The likelihood that they will leave the regulating jurisdiction therefore decreases, reducing the impact of $e_{2}$ on the regulatory calculus. This point holds true across any global governmental system we can imagine: the larger the governmental jurisdictions within a finite global system, the fewer governments there will be and the smaller the $e_{2}$ will be for any given government.

In the end, then, because Congress represents a larger constituency and a larger land mass, its incentives to regulate will be less distorted than the states' incentives to regulate in every single regulatory regime. As a general matter, externalization is less of a problem for Congress than it is for a state legislature.

\section{The Ubiquity of Externalization}

The problem with interstate externalization as a justification for congressional control is that it occurs, to varying degrees, in every regulatory regime. Because the citizenry is freely mobile, there is not a single regulatory question that does not experience some externalization of costs or benefits. Take the example that Cooter and Siegel give of a local question: the building and maintenance of an ordinary public park. ${ }^{28}$ For the most part, the people who live close to a city park will be the ones to enjoy it, and those people will have an incentive to keep the park in good condition. But tourists from other states will also be able to access the park, and any benefits they derive from it or harms they impose on it (by littering, for example) will be impossible for the park's home state to recoup through taxation. The $e_{1}$ for public parks, therefore, is non-zero; some of the benefits of the park accrue to other states, and some of the costs of the park derive from other states. Each state, thus, has an incomplete incentive to build and maintain public parks. In other words, each state's willingness to pay for such parks is less than would be optimal from an interstate perspective. (Cooter and Siegel somewhat ironically use New York City's Central Park to start this discussion of their paper, which is of course unusual among city parks for the number of out-of-state visitors it attracts. ${ }^{29}$ Even an ordinary public park might get an occasional out-of-state visitor, though, who will gain benefits and impose costs that the home state cannot recoup directly, imposing some $e_{1}$ on the state's decisional calculus.)

Similarly, Cooter and Siegel argue that the Supreme Court's decisions in United States v. Lopez ${ }^{30}$ and United States v. Morrison ${ }^{31}$ are correct under their theory because, they assert, neither gun possession near schools nor violence against

${ }^{27}$ For the sake of simplicity, I assume here that the cost to the manufacturer of moving from Massachusetts to New Hampshire is the same as the cost to the manufacturer of moving from Massachusetts to China. That assumption is obviously inaccurate, both in terms of the practical costs of moving and in terms of the political and social costs of outsourcing. The distinction, though, cuts in favor of my point here that the $e_{2}$ will be less for national action than for state action; it will be much more likely that a regulated entity will move from state to state (harming the first state to regulate) than that a regulated entity will move from nation to nation (harming the first nation to regulate).

${ }^{28}$ Cooter \& Siegel, supra note 3, at 137-38 (distinguishing between large parks on mountaintops, which are likely to attract visitors from all over the country and are therefore national parks, and small city parks, which are likely to benefit primarily the citizens who live close by).

\footnotetext{
${ }^{29} \mathrm{Id}$. at 137.

${ }^{30} 514$ U.S. 549 (1995).

${ }^{31} 529$ U.S. 598 (2000).
} 
women causes interstate coordination problems. ${ }^{32}$ In starting their discussion of Lopez, Cooter and Siegel explicitly contend that "the absence of regulation of guns near schools in one state would not undercut the effectiveness of regulations prohibiting them in other states." 33 They base this argument, though, on a narrow view of the purposes and effects of the Gun-Free School Zones Act (GFSZA), focusing exclusively on the costs to the state of actually enforcing a prohibition of gun possession near schools and broadening the question only so far as to encompass regulation of gun markets. ${ }^{34}$ From that narrow perspective, Cooter and Siegel are right that one state's refusal to enact a GFSZA would have no impact on another state's ability to enforce such a prohibition at home. But that's not the law's only purpose or effect.

Part of the government's theory in Lopez was that gun violence in schools decreases the quality of education, producing citizens who are less able to contribute meaningfully to the national economy. ${ }^{35}$ Furthermore, it is undoubtedly true - even outside the stylized arguments that the government needed to make for a Commerce Clause defense in Lopez - that Congress passed the GFSZA in part to address the disaffection of American youth that was resulting from the increasing presence of guns, gangs, and violence in primary and secondary education. ${ }^{36}$ Imagine, then, that every state except Texas (where I was born and raised) enacted a GFSZA. Assuming that the government's causal story in Lopez is right, the average Texan in this scenario would be more disaffected and less educated than the average citizen of any other state and might also tend more towards criminality than the average American. But the Texans would not all stay in Texas. Many of them (like me) would move to other states and would attempt to find work there, frustrating the other states' attempts to bolster their economies and decrease their crime rates with the GFSZA. The presence within the other states' borders of poorly educated and disaffected Texans would continue to impose some guns-in-schools-related costs on the other states' economies. Furthermore, Texas would not suffer the full cost of refusing to reduce gun violence in its schools. Many individuals educated in other states would move to Texas to work there, and many of the criminal youth that Texas produced would wind up imprisoned in other states. The Texas economy, thus, would not be as bad as one would predict from Texas's lack of a GFSZA. Each state's willingness to pay for the regulation is therefore less than the social optimum because a regulating state will not capture the full social benefit of producing better-educated and happier citizens.

Congress, on the other hand, has an incentive that is closer to the optimum. Congress's incentive is less distorted than any state's because there is less in- and out-migration across countries than across states. Again, this point is mathematically true of any large government because the average distance one needs to travel to escape a large government is greater than the average distance one needs to travel to escape a small government. Of course, Congress's willingness to pay will not be perfect because people can and do move internationally, but the point is that Congress is structurally better suited to internalize costs and benefits than the states.

${ }^{32}$ Cooter \& Siegel, supra note 3, at 163.

${ }^{33} \mathrm{Id}$.

${ }^{34}$ See id. at 163-64.

${ }^{35}$ Lopez, 514 U.S. at 564

${ }^{36}$ See generally Louis Harris, A SuRVey of EXPeriences, Perceptions, AND APPREHENSIONS About Guns Among Young People In America (1993) (using survey data to document an increase in gun possession in schools). 
This same story plays out with respect to the Violence Against Women Act (VAWA) that was at issue in Morrison. ${ }^{37}$ In that case, the government argued that VAWA would reduce economic costs caused by the intimidation, abuse, and marginalization of women - that the statute would help women to contribute meaningfully to the economy.$^{38}$ Imagine again that every state except Texas enacted a VAWA, reducing the incidence of domestic violence within their borders and producing better and more productive women as a result. As with the less-welleducated Texans in the GFSZA case, the less-productive Texan women in the VAWA case would not all stay in Texas, and they would, upon moving, undercut the other states' attempts to improve their economies. Furthermore, some self-assured and confident non-Texan women might move in to Texas, helping the state to avoid the full economic cost of refusing to pass a VAWA.

Notably, these externalities are not the pure hedonic externalities that Cooter and Siegel acknowledge. ${ }^{39}$ The problem is not that Louisianans might be saddened by the domestic violence or educational deficiencies that their neighbors experience. It is instead that Texas's policy choices impose concrete costs on Louisiana's economy when insecure women and disaffected youth from Texas move into Louisiana's jurisdiction. And the likelihood of that externality's occurrence distorts both Texas's and Louisiana's willingness to pay for their own GFSZA and VAWA regulations.

Ultimately, under a pure externalization theory of regulation, Congress will always internalize more regulatory costs and benefits and will therefore always regulate better than the states. The regulatory incentives of a larger government will always be closer to the optimum than the regulatory incentives of a smaller government.

\section{Two Empirical Limits of Collective Action Federalism}

There are two complexities that might arise in the simple model of externalization, and both complexities might limit the centralizing push of collective action federalism. First, the simple assertion that no government has an optimal incentive to regulate does not prove that no government will regulate optimally. Some externalities might be harmless. Second, each jurisdiction might internalize other states' externalities in a way that counterbalances its own externalization, neutralizing any harmful externality. I will flesh out each of those possibilities in turn, but I will then proceed in Part II.A.4 to explain why neither provides a satisfying justification for Cooter and Siegel's internalization principle as stated.

\section{a. Harmless Externalities}

Let's return to the stylized hypothetical from Part II.A.1: externalized pollution reduces Massachusetts's willingness to pay for pollution abatement laws from the optimum of 100 utils to a suboptimum of sixty-five utils. But what would happen if Massachusetts could enact a fully effective regulation at a social cost to its residents of only sixty-four utils? In that case, Massachusetts might well pass a pollution abatement law that would eliminate all 100 utils of Massachusetts-produced environmental harm, even though the state's incentive to regulate was imperfect. In

\footnotetext{
${ }^{37}$ United States v. Morrison, 529 U.S. 598 (2000).

${ }^{38}$ See id. at 634-36.

${ }^{39}$ Cooter \& Siegel, supra note 3 , at 154-55.
} 
other words, there is a distinction, which Cooter and Siegel don't draw but could, between a distortion in regulatory incentives and a distortion in regulatory outcomes.

Notably, the possibility that this story will play out - that a state with a distorted incentive to regulate will nevertheless reach an optimal regulatory result-does not depend solely on the magnitudes of the externalities, costs, or benefits. It also depends on the ratio between costs and benefits. The closer that ratio is to one (the closer the costs and benefits are to being equal), the more likely it is that an externality will affect regulatory outcomes. Take the public parks example. The magnitude of the externality for most public parks is likely to be extremely small. The city park in downtown Billings, Montana, probably gets very few out-of-state visitors each year. But that point alone doesn't imply that the externality doesn't matter. If Montana needs to expend 100 utils in order to build and maintain a park that produces 100 utils of total social benefit, then any externalization of any magnitude will cause under-production of parks. The externalization will be harmless only if its magnitude is less than the difference between costs and benefits-if, for example, Montana needs to spend ninety utils to produce 100 utils of benefit and the state externalizes less than ten utils.

Nevertheless, the possibility of a harmless externality provides one potential limit for collective action federalism. There might be many regulatory regimes in which the ratio of costs to benefits is usually less than one and in which the externalities are not high enough to distort regulatory outcomes; in those regimes, rational states will reach optimal results despite their suboptimal willingness to pay.

\section{b. Counterbalancing Externalization}

The second possible limit on collective action federalism rests in the possibility that an equal or greater in-migration of benefits could counterbalance the outmigration of benefits. The easiest example of this point is the example of Central Park, an ordinary city park (from a legal perspective) that attracts an extraordinary number of out-of-state tourists. To keep things concrete with numbers, imagine that Central Park provides 100 utils of total social benefit to the individuals who visit the park each year; they play in the park, enjoy the green space, visit the zoo, etc. Imagine that twenty percent of those visitors are tourists from other states, decreasing New York's internalized social benefit to eighty utils $\left(e_{1}=20\right)$. Let's further imagine that the out-of-state visitors impose costs of ten utils on the park in the form of congestion, littering, rock and trail erosion, grass trampling, etc., and that New York has no means of recouping those ten utils through taxation or user fees extracted from the tourists $\left(e_{2}=10\right)$. New York's willingness to pay for Central Park, on this simple model, is seventy utils-less than the optimal 100 utils.

It is possible, however, that the tourists' presence in Central Park provides income to New York that is externalized to the tourists' home states. For example, imagine that the tourists transfer some of their utils to New York by buying hot dogs from Central Park vendors, hotel rooms from nearby establishments, Frisbees from abutting sporting goods stores, etc. All of that income to New York comes out of the tourists' home economies, and it provides some counterbalance to the externalities that New York experiences. If that counterbalance totals exactly thirty utils, then New York's incentive to build and maintain Central Park becomes perfectly optimal again. If it is more or less than thirty utils, then the optimality of New York's regulatory result depends on the constraint described in the prior subsection-the possibility that the overall externality is harmless. 


\section{The Legal Problem with Collective Action Federalism}

I noted at the outset of Part II.A that the legitimacy of Cooter and Siegel's internalization principle depends critically on whether power should flow to the smallest unit of government that internalizes all of the effects of its exercise or to the smallest unit of government that internalizes most of those effects. The two empirical limits described above might provide some content to the word "most" in the second formulation, and that might be what Cooter and Siegel intended to argue. But that principle is unsatisfying for two reasons.

First, from a legal and constitutional perspective, it would be nice if a theory of federalism provided some generalizable principle for assigning authority among governments. Under the models for collective action federalism, the permissibility of congressional action depends on extremely difficult and extremely specific empirical evaluations of the costs, benefits, and externalities of each and every regulatory question (not just each regulatory regime) ${ }^{40}$ Under the externality theory, it is impossible to say, for example, that the states generally should have authority over education because the cost-benefit ratio for teaching evolution or Huckleberry Finn will be different from the cost-benefit ratio for teaching arithmetic or Jane Eyre and because the harmful externalities associated with ignorance of evolution will be different from the harmful externalities associated with ignorance of basic math.

The second problem with Cooter and Siegel's internalization principle is that it provides no justification for defaulting to the smallest unit of government. The models here argue for the opposite presumption of regulatory authority because Congress is structurally better-suited than the states to internalize regulatory costs and benefits and is therefore structurally better-suited to follow optimal regulatory calculi. ${ }^{41}$ Internalization scales directly (rather than inversely) with a government's size. Why not, then, set a rule that we should assign regulatory power to the largest unit of government that can access reliable information about the costs and benefits of a regulatory question? Or a rule that we should assign regulatory power to the largest unit of government that has a plausible claim to democratic legitimacy? Or to the largest unit of government that currently exists? Any of those rules would do better at combating collective action problems than Cooter and Siegel's default to smallness.

But, of course, the problem with a default assumption of congressional authority - and more generally with an internalization principle for deciding constitutional federalism questions - is that a focus on externalization misses something important about the American federal system, something that Cooter and Siegel acknowledge in passing without ever addressing directly: state power has its own structural regulatory advantages.

\section{B. LIBERTARIAN FEDERALISM}

Unlike collective action federalism, libertarian federalism is not yet a welldeveloped theory in the legal literature. Rather, it is an assertion that the Eleventh Circuit $^{42}$ and others ${ }^{43}$ have made in passing while arguing against the individual

\footnotetext{
${ }^{40}$ See Cooter \& Siegel, supra note 3, at 135-44.

${ }^{41}$ See supra Part II.A.1.

${ }^{42}$ Florida ex rel. Att'y Gen. v. U.S. Dep't of Health \& Human Servs., 648 F.3d 1235, 1284 , 1291-92 (11th Cir. 2011), cert. granted sub nom. Nat'l Fed'n of Indep. Bus. v. Sebelius, $132 \mathrm{~S}$. Ct. 603 (2011) (mem.), and cert. granted, 132 S. Ct. 604 (2011) (No. 11-398) (mem.) (argued Mar. 26-27, 2012), and cert. granted in part, 132 S. Ct. 604 (2011) (No. 11-400) (mem.) (argued Mar. 28, 2012)
} 
mandate. The theory, in its limited form, simply contends that the purpose of the American federal structure is to preserve individual liberty. But how does it do that? Preservation of liberty comes from two structural features of federalism. First, American federalism encumbers the law-making process by housing authority in fifty competing sovereigns, systematically decreasing the number of intrusive laws that can pass. Second, smaller units of government give individuals greater opportunities to influence regulatory decisions and more opportunities to flee regulatory outcomes that they dislike.

As should be apparent from that brief description, the theory of libertarian federalism does not depend at all on substantive categories of liberty, like the freedoms of speech, religion, contract, or bodily autonomy. The kind of liberty at issue here is a generalized freedom from governmental restraint. The question for Obamacare under this theory, then, is not whether the insurance mandate violates individual rights in a way that ought to receive scrutiny under the Fifth Amendment, but rather whether strongly felt individual objections to the mandate ought to counsel in favor of state control.

The first step in making this argument is to examine whether and how the states can address multi-state regulatory needs if they do not act through Congress. That discussion highlights two features of pure state power that track the two structural points above (the general barrier to regulation and the preservation of regional power), which I will flesh out in greater detail. Next, I will explain why the libertarian theory pushes monotonically towards diffusion of regulatory authority. Like the collective action theory, the libertarian theory needs some kind of limiting principle in order to be a theory of federalism.

\section{Multi-State Coordination and Coasean Federalism}

The first step in understanding libertarian federalism is to ask whether and how the states can act in their collective interest if not through national congressional regulation. As Cooter and Siegel point out, the externalities among the states would make no difference to regulatory results if transaction costs among the state governments were zero. ${ }^{44}$ Consider again the hypothetical above: if Massachusetts externalizes twenty-five utils worth of pollution-related harms onto New Hampshire and Rhode Island, then those states should be willing to pay Massachusetts twentyfive utils to implement pollution abatement laws. On the same rational-actor model of regulation that applied to Massachusetts itself, New Hampshire and Rhode Island should be willing to pay for pollution abatement in Massachusetts up to the point that the benefits to New Hampshire and Rhode Island of such laws equal the costs. Any state that suffers harm from an absence of regulation-whether that harm is produced in and externalized from another state or not-should be willing to pay for harm-reducing regulation up to the point that the cost of the regulation equals its benefits. On the working assumption that Massachusetts externalizes twenty-five utils of harm, the states that suffer from that externality should be willing to transfer twenty-five utils to Massachusetts in exchange for full pollution abatement. A

(noting at the outset that the "ultimate goal" of "structural constitutional limitations" is "the protection of individual liberty" and that the mandate's perceived intrusion on freedom "strikes at the very heart of whether Congress has acted within its enumerated power").

${ }^{43}$ See generally supra note 8 and sources cited therein.

${ }^{44}$ See Cooter \& Siegel, supra note 3, at 139-44. This point is simply an application of the Coase theorem. See generally R. H. Coase, The Problem of Social Cost, 3 J.L. \& EcON. 1 (1960). 
transfer $\left(t_{1}\right)$ equal to the externality $\left(e_{1}\right)$ would restore optimality in Massachusetts's willingness to pay:

$$
\text { If } t_{l}=e_{l} \text {, then } W T P=S B_{r}-e_{1}+t_{l}=S B_{r} \text {. }
$$

Furthermore, states may constitutionally enter into these kinds of regulatory compacts (without congressional oversight or approval) as long as the compacts do not tend "to increase the political power in the States" in a way that "encroach[es] upon or interfere[s] with the just supremacy of the United States." regulatory compacts to pay for each other's laws and law enforcement are constitutionally permissible. ${ }^{46}$ In theory, then, a central government is entirely unnecessary to address interstate externalities; assuming zero transaction costs, states will bargain to the most efficient result. ${ }^{47}$

But, of course, transaction costs are not zero. It is difficult for states to enter into regulatory compacts, particularly because individual states can hold out and render compacts ineffective for any regulatory problem that requires universal participation among the states. In discussing this holdout problem, Cooter and Siegel conclude that requiring interstate cooperation through compacts effectively sets a unanimity requirement for multi-state regulation, ${ }^{48}$ compared to the majority requirement that theoretically applies when the states cooperate through Congress. ${ }^{49}$ In their view, a regulatory problem that requires all fifty states to act is virtually impossible to address through coordinated action because a unanimous vote in a fifty-member body is extremely unlikely. ${ }^{50}$

Although Cooter and Siegel's argument is fundamentally right, it contains a simplification that causes the authors to miss something important about federalism: they treat the states as monolithic voting units, rather than focusing on the people who comprise them. In the eyes of a libertarian federalist, the relevant question is whether a majority of individual voters favor a regulatory intervention. And although the cooperation requirement is (as Cooter and Siegel note) a requirement for state unanimity, it is not a requirement for popular unanimity. ${ }^{51}$ Imagine, then, that a majority of American voters nationwide favor a regulatory intervention, and assume for simplicity that all states make decisions through majority rule in which representation works perfectly. ${ }^{52}$ Under these conditions, the success or failure of regulation through compacts depends on the distribution of the national majority. If that majority were comprised of mere majorities in every state, the compact system would work. If, however, the national majority were comprised of supermajorities in

${ }^{45}$ See Virginia v. Tennessee, 148 U.S. 503, 519 (1893) (interpreting and applying the Compacts Clause of the Constitution, U.S. CONST. art. I, $\S 10$, cl. 3 ).

${ }^{46}$ See generally U.S. Steel Corp. v. Multistate Tax Comm’n, 434 U.S. 452 (1978).

${ }^{47}$ See Coase, supra note 44.

${ }^{48}$ See Cooter \& Siegel, supra note 3 , at 140-41.

49 Congress, of course, is not really a majority voting system. The Senate's filibuster rule requires a sixty percent vote among states, and the Senate's equal representation of states requires far more than a sixty percent vote among the American populace. Nevertheless, the three-fifths voting requirement in the Senate is an easier hurdle to overcome than the unanimous voting requirement for compacts.

${ }^{50}$ See Cooter \& Siegel, supra note 3 , at 141 .

${ }^{51}$ Id. at 140-41.

${ }^{52}$ Forty-nine state legislatures (all but Nebraska) have two chambers and therefore more closely resemble supermajority rule. Unlike Congress, though, all state legislative districts abide by proportional representation requirements; only the national Senate violates the one-person, one-vote requirement. Furthermore, representation is imperfect, and it is certainly possible that a regulation could fail despite majority or even supermajority popular support or that a regulation could pass despite majority or even supermajority popular opposition. 
some states and minorities in others, compact-based regulation would work partially or fail entirely; the states with only minority support for the regulation would refuse to enter the compact.

How does that compare to Congress? Assuming majority rule and perfect representation, Congress would be able to pass any regulation that had majority support nationwide so long as the regulation had majority popular support in a mere majority of states. The House of Representatives ensures that nationwide majority support is required, but the Senate allows a mere majority of states to control national regulatory outcomes. Imagine, then, that fifty-one percent of the population in each of twenty-six states favored a regulatory intervention but that seventy-five percent of the population in each of the remaining twenty-four states opposed the regulation. Imagine further that the twenty-four objecting states were among the least populous and that the regulation therefore had majority popular support in the country as a whole. The House of Representatives would pass the regulation based on majority support nationwide, and the Senate would pass the regulation based on majority support in a majority of states. The fifty-two Senators from the twenty-six supportive states would pass the law over the objections of the forty-eight Senators from the twenty-four opposing states. Congress, thus, can pass an intervention over the strong objections of a regional popular supermajority.

Cooter and Siegel are of course right that the probability of garnering majority support in every voting unit decreases as the number of voting units increases. Requiring majority popular support in every state undoubtedly makes regulations harder to pass than requiring majority popular support in a majority of states. The point here is just that the problem with compact-based regulation is not quite as bad as Cooter and Siegel imply; it is theoretically possible for compacts to pass with mere majority popular support nationwide. And as we shall see, the preservation of state sovereignty, the requirement for state acquiescence in national regulation, and the difficulties that come with a state-based unanimity requirement were all part of the constitutional design, intended as checks against anti-libertarian incursions.

\section{Collective Action Problems, Regional Differentiation, and Liberty}

The possibility of national regulation through interstate compacts highlights two features of state power that are desirable from a libertarian federalist's perspective. First, by giving power to fifty competing sovereigns that must cooperate to regulate, federalism helps to ensure that implemented regulations are truly necessary and preferred. Second, by requiring unanimity among the states for national regulation, federalism empowers individual voters to influence the national regulatory process through their state governments, either by voicing their opinions in their states or by moving from a pro-regulatory state to an anti-regulatory state in order to increase the power of an oppositional majority (or vice versa). Both of these features of federalism empower individuals relative to governments, structurally preserving freedom from unwanted regulatory intrusions.

\section{a. Compacts, Information, and Tyranny}

The first libertarian benefit of state power relates to informational problems in regulation. It is of course true that Congress can regulate more quickly and efficiently than the states. There is someone who can regulate more quickly and efficiently than Congress, too: King George III. The benefit of diffusing regulatory power is that it checks against governmental abuse and tyranny. Compact-based 
regulation is harder to enact than congressional regulation, but that difficulty is a feature, not a bug, of the American federal system.

This view is based on two interrelated premises. First, regulators are selfinterested individuals who will, if able, use their power to favor themselves over the general welfare (i.e., the assumption of perfect representation is deeply fictional). Second, voters will have a hard time monitoring their representatives' self-interested tendencies. ${ }^{53}$ To put the first premise in the economic terms of the collective action theory, the concern here is that a regulating class will be able to capture excessive benefits for itself by externalizing the costs of those benefits onto the regulated class. ${ }^{54}$ Notably, this kind of tyranny needn't push systematically towards overregulation. A ruling class made up primarily of employers, for example, might refuse to pass welfare-enhancing legislation that would protect collective bargaining rights of employees, and that under-regulation would also be due to tyrannical externalization rather than interstate externalization. The only mechanism for combating that kind of externalization is the periodic election of the regulators by the regulated, but that mechanism will fail if voters have incomplete information about the magnitude and distribution of a legislative proposal's costs and benefits.

In other words, if we had perfect information about the costs and benefits of a particular regulatory question, the monitoring feature of state power would be entirely unnecessary. Any governmental entity could identify the optimal regulatory outcome, taking account of all relevant interests for all affected individuals, and voters would know when a legislature (whether state or national) was refusing to regulate optimally. ${ }^{55}$ Both regulatory outcomes and government's accountability for those outcomes would function well, and voters could trust Congress (or King George) with its greater regulatory speed and efficiency.

But we do not have perfect information. The costs and benefits of regulations are complex and obscure to both legislators and voters, providing slack in the legislator-voter relationship that the ruling class can exploit for its own gain. Furthermore, information is likely to be asymmetric with respect to many regulatory questions, with regulators holding more information than voters, which allows regulators to justify self-interested outcomes in terms that are not transparently selfserving.

The coordination problems among the states help to prevent these kinds of abuses in three ways. First, requiring cooperation among competing sovereigns reduces the likelihood of insidious collusion among the regulating class. Assuming that Massachusetts and New Hampshire are competing for desirable residenttaxpayers, ${ }^{56}$ New Hampshire legislators will have an incentive to blow the whistle on Massachusetts legislators if Massachusetts proposes a conspiratorial compact to benefit the ruling class. In other words, the multi-lateral prisoners' dilemma that

${ }^{53}$ See, e.g., Einer Elhauge, Does Interest Group Theory Justify More Intrusive Judicial Review?, 101 YALE L.J. 31, 34-44 (1991).

${ }_{55}^{54}$ See generally Cooter \& Siegel, supra note 3.

${ }^{55}$ It is for this reason that I have argued elsewhere for greater nationalization of healthcare policy, on the ground that healthcare regulation is increasingly objectivist and therefore transparent in its costs and benefits. See generally Moncrieff \& Lee, supra note 12; Abigail R. Moncrieff, The Supreme Court's Assault on Litigation: Why (and How) It Might Be Good for Health Law, 90 B.U. L. REV. 2323 (2010).

${ }^{56}$ See generally Charles M. Tiebout, A Pure Theory of Local Expenditure, 64 J. PoL. ECON. 416 (1956) (modeling interstate competition and theorizing that such competition could theoretically result in optimal regulatory bundles). 
results from the mobility of the citizenry ${ }^{57}$ works to the cops' advantage in this case just as it does in any standard prisoners' dilemma. That is, just as coordination problems among prisoners lead the prisoners to confess, providing more information to the police, the coordination problems among the states will cause regulators in one state to confess to other state's tyrannical compact proposals, providing more information to voters (the metaphorical cops in this story). In Congress, by contrast, the members are not in direct competition with one another and are therefore less likely to reveal each other's collusive proposals. ${ }^{58}$

Second, each representative is structurally more accountable when government is smaller, making monitoring easier. This is so for three reasons. First, each voter has a greater individual stake in regulatory outcomes when government is regulating fewer people, and each individual voter therefore has a stronger incentive to monitor representatives when government is smaller. That is, the free-rider problem in voting systems and accountability structures is less severe for smaller governments than for bigger ones. Second, each voter has greater access to her representative when the representative has fewer constituents. Direct conversations with the representative are significantly more likely to occur for smaller governments than for bigger ones, making it easier to challenge a representative on a questionable regulatory decision when government is smaller. Third, the costs and benefits of regulation are easier to assess when government is smaller, reducing the information asymmetry between regulators and voters. I can be more confident in my sense of majority needs and preferences in my law school community than in my university community, in my university than in my city, in my city than in my state, etc., because I am closer to my fellow constituents in smaller governments than in larger ones. If my law school enacts a welfare-reducing rule, I will be more likely to notice and object than if my university does so, or my city, state, or nation. ${ }^{59}$

Third, simply by increasing the difficulty of regulating, state power makes it less likely that any regulation will pass, which necessarily makes it less likely that tyrannical or factional regulation will pass. There are two important points about this idea. First, the argument is not that suboptimal regulation is good (a view commonly attributed to libertarians); it is that the costs of suboptimal regulation might be a reasonable price to pay to avoid tyrannical regulation. ${ }^{60}$ This point takes an explicitly

\footnotetext{
${ }^{57}$ See supra Part II.A.1 for the discussion of externality $e_{2}$.

${ }^{58}$ The two-party system creates one kind of direct competition, but it does not prevent collusion within a single party, which might be enough to allow tyrannical regulation of the relevant kind.

${ }^{59}$ Anti-Federalist George Clinton made all of these points in arguing against the adoption of the Constitution:

[W] hat can you promise yourselves, on the score of consolidation of the United States into one government? Impracticability in the just exercise of it, your freedom insecure, even this form of government limited in its continuance, the employments of your country disposed of to the opulent, to whose contumely you will continually be an object. You must risk much, by indispensably placing trusts of the greatest magnitude, into the hands of individuals whose ambition for power, and aggrandizement, will oppress and grind you. Where, from the vast extent of your territory, and the complication of interests, the science of government will become intricate and perplexed, and too mysterious for you to understand and observe; and by which you are to be conducted into a monarchy, either limited or despotic; the latter, Mr. Locke remarks, is a government derived from neither nature nor compact.

George Clinton, Republican Government: Cato, No. 3, in 1 The Complete Anti-Federalists 126 , 126 (Herbert Storing ed., University of Chicago Press, 1981).

${ }^{60}$ Notably, tyrannical or self-serving regulation is not always the same thing as over-regulation. Refusal to implement equality protections for racial minorities, for example, might serve the interests of the regulating class even though it involves less governmental intrusion.
} 
rule-utilitarian view of governmental structure. The idea is that no governmental system, under our real-world conditions of limited and asymmetric information, will produce optimal regulation, and we therefore need to choose between imperfect options. The option of decentralized and competitive power among states will result in under-regulation, but the option of centralized and monopolistic power in Congress will result in abusive regulation. To avoid the costs of tyranny, we pay in stagnation. ${ }^{61}$ Second, the argument is not that collective regulation should never happen but rather that it should happen only when the vast majority of people nationwide believe that it should happen. In discussing the problem of public goods provision, Cooter and Siegel note that interstate externalities and free-rider problems justify central provision of national defense. ${ }^{62}$ But, of course, the states fought and won the American Revolution without such centralized constitutional authoritythrough a loose contractual affiliation in the Continental Congresses and relying primarily on separately governed state militias. ${ }^{63}$ When coordinated action is truly necessary, the states can and will cooperate. Furthermore, the converse is true: when the states enter into compacts for national regulation, voters can be confident, despite their informational deficits and asymmetries, that the regulation is truly necessary.

In short, under the theory of libertarian federalism, the difficulties of regulating that come with state control are to be celebrated, not combated. The reason for this view, though, is not that markets are better than governments at regulating- the view of standard libertarianism. For a libertarian federalist, the reason to celebrate state power is that small, competitive governments are structurally better than big, monopolistic governments at protecting against regulatory abuses.

\section{b. Regional Majorities, Voice, and Exit}

The other libertarian virtue that comes with state power similarly arises from the requirement that majorities in every state, not just in a majority or even supermajority of states, agree to a national regulation. This feature of state power creates the possibility that a national minority can satisfy its regulatory preferences by establishing a state majority, better preserving every citizen's freedom to escape unwanted regulatory interventions. Three structural features of state power are necessary for this possibility to occur: State control allows citizens of different states to diversify in their regulatory approaches (diversity). It allows each citizen to lobby more effectively for change (voice). And it allows citizens to move from one regulatory jurisdiction to another (exit). In this sense, the mobility of the citizenry (although it causes regulatory externalities) and the unanimity requirement of state

${ }^{61}$ This point, too, appears in the Anti-Federalist papers:

$[F]$ or the sake of argument, I will admit that the necessary consequence of rejecting or delaying the establishment of the new constitution would be the dissolution of the union, and the institution of even rival and inimical republics; yet ought such an apprehension, if well founded, to drive us into the fangs of despotism? Infinitely preferable would be the occasional wars to such an event. The former, although a severe scourge, is transient in its continuance, and in its operation partial, but a small proportion of the community are exposed to its greatest horrors, and yet fewer experience its greatest evils; the latter is permanent and universal misery, without remission or exemption. As passing clouds obscure for a time the splendor of the sun, so do wars interrupt the welfare of mankind; but despotism is a settled gloom that totally extinguishes happiness.

Centinel, Union: Centinel, No. 11, in 1 The Complete ANTI-Federalists, supra note 59, at 231.

${ }^{62}$ See Cooter \& Siegel, supra note 3, at 136.

${ }^{63}$ See The American Constitution: For And Against 3-6 (J.R. Pole ed., 1987) (describing the coordinating efforts that the colonies made to fight the Revolutionary War). 
power (although it causes stagnation) are both features rather than bugs of the federal system.

First, one of the primary advantages of state control is that it allows for regional diversity. Of course, such diversity is undesirable if there is an identifiable first-best regulatory approach that applies in all jurisdictions. But even if voters had perfect information about a regulation's costs and benefits, optimality might vary geographically. The cost of requiring clean coal, for example, is greater in the East than it is in the West, while the cost of requiring coal scrubbing is greater in the West than it is in the East. ${ }^{64}$ When the Environmental Protection Agency (EPA) faced the difficult challenge of setting a single emissions-reduction regulation for the entire country despite differing regional cost-benefit curves, it necessarily regulated non-optimally for one of the affected regions. ${ }^{65}$ It might have chosen the optimal outcome under a constraint of monolithic national policy-making, but it certainly chose a non-optimal outcome for some regions. If the states had been in charge instead, it would have been possible for different states with different cost-benefit curves to implement different regulations, and the end result might have better approximated national optimality than the EPA's monolithic approach, notwithstanding the interstate externalities associated with coal-burning power plants. Similarly, if voters in Texas have different preferences than voters in Massachusetts with respect to the level of governmental involvement in their healthcare decisions, it might make sense to let Texas citizens regulate healthcare differently than Massachusetts citizens, even though (like coal pollution) healthcare regulation suffers from interstate externalities.

Second, for the same reasons that individuals will have an easier time monitoring representatives when governments are smaller, they will have an easier time affecting regulatory decisions when governments are smaller. If each representative has fewer constituents, then each constituent has a greater incentive and a greater ability to communicate her preferences to her representative. The probability that a representative will hear her constituent's voice and respond to it increases as the size of the representative's constituency decreases. It is therefore plausible that a bare state majority that seeks state regulation is more likely to succeed than a bare national majority that seeks national regulation, even assuming that the state and national governments have identical majority voting rules. Representation works better at the state level.

Third, state power provides greater opportunities than national power for individuals to leave a disfavored regulatory regime for a preferred one. Of course, international mobility is possible, but interstate mobility is easier. This feature of state power similarly allows individuals to influence the regulations to which they are subject simply by moving to the state that has the most attractive bundle of regulations.

In short, state power provides structural freedom to individuals that monopolistic, monolithic national power cannot provide. State control gives citizens more and cheaper opportunities to choose the kinds of governmental restraints they will tolerate.

\footnotetext{
${ }^{64}$ See generally Bruce A. Ackerman \& William T. Hassler, Beyond the New Deal: Coal and the Clean Air Act, 89 YALE L.J. 1466 (1980) (describing the odd dirty coal/clean air coalition that formed during implementation of the Clean Air Amendments in a 1979 ruling by the Environmental Protection Agency (EPA)).

${ }^{65}$ See id. at 1483-87 (describing the EPA's decision-making process).
} 


\section{The Monotonically Decentralizing Push of Libertarian Federalism}

Just as collective action federalism pushes monotonically towards centralization of power, libertarian federalism pushes monotonically towards diffusion of power. Smaller, competitive governments will always be better at checking tyranny and at facilitating diversity, voice, and exit. For every regulatory regime, smaller governments will be structurally better-suited than bigger governments to protect individual liberty. Even for classic public goods like national defense, smaller governments can accomplish any needed regulation through treaties and compacts, just as the American colonies did to fight the Revolution and just as today's Western nations do through the North Atlantic Treaty Organization.

The problem with the theory, then, is that without a limiting principle, libertarian federalism argues for the dissolution of the national government. The United States should, if libertarian federalism is taken to its natural conclusion, disband into fifty nations and negotiate their collective interests through compacts. From a legal and constitutional perspective, then, libertarian federalism does not provide a workable test. The constitutional answer cannot be that the enumeration of national powers is meaningless and that the United States should disband-nor should the constitutional answer be that the enumeration should be read as narrowly as the words will allow. Such a reading would not do justice to the Framers' intent or to the document's modern meaning.

\section{Cost-Benefit Federalism}

Given that both collective action federalism and libertarian federalism rest on foundationally correct visions of government but that each theory taken alone would argue for the end of federalism, we need some way to reconcile the two. Fortunately, there is an easy theoretical answer. The best federalist balance is the one that optimizes the benefits of regulatory efficiency within the constraint of libertarian costs (or, the same rule, that optimizes the benefits of individual liberty within the constraint of efficiency costs). Indeed, the same cost-benefit constraint that applies to each government's regulatory decision should apply to the structural constitutional decision. We should be willing to centralize authority up to the point that the costs of centralization equal the benefits, where the costs are measured in terms of the liberty lost and the benefits in terms of the efficiency gained. Centralization should be allowed whenever:

$$
S B_{c} \geq S C_{c}
$$

The question, then, ought to be whether a proposed national regulation will gain enough in correction of interstate externalities to be worth the losses to structural libertarian virtues.

This rule has three advantages over the two competing theories. First, it incorporates all of the foundational correctness of the other two views. Second, it is truly a theory of federalism rather than a theory of either nationalism or statism; it captures the advantages of both state and national governance, as the American federal structure is intended to do. Third and most interestingly, it provides a generalized guideline for which regulatory regimes ought to be nationalized and which ought to be left to states. Put most obviously, the guideline is that regimes in which liberty is more important than efficiency should be left to states while regimes in which efficiency is more important than liberty ought to be given to Congress. A more nuanced way to put the same point is that regimes in which the costs and benefits are primarily subjective and preference-based ought to be left to states while 
regimes in which the costs and benefits are primarily objective and needs-based ought to be given to Congress. Yet another verbal formulation is that regulations whose primary benefit is their expression and facilitation of voters' preferences should be left to the states while regulations whose primary benefit is their realworld effects should be given to Congress. This is so for two simple reasons: First, subjective harms have a harder time traveling across state lines than objective harms, and the harms that do travel are unlikely to change subjectively based regulatory decisions (i.e., externalities are quite likely to be harmless). Second, in the American constitutional system, liberty is generally more important in subjective regimes than in objective regimes.

Take the point about externalities first: where regulatory optimality depends primarily on voters' subjective preferences rather than their objective needs, interstate externalities are very unlikely to impact regulatory decision-making. For example, the subjective preference for protecting traditional marriage in Maine will cause externalities for Vermont, but those externalities are very unlikely to impact Vermont's decision to protect gay marriage. That is, because of its marriage protection law, Maine might produce homophobic straight citizens who will carry their homophobia with them when they travel to Vermont, and it might produce traumatized gay citizens who will carry their psychological ill-health with them when they travel to Vermont. ${ }^{66}$ Both of those externalities will distort Vermont's regulatory cost-benefit curve. Vermont will not capture the full benefit of allowing gay marriage because some homophobia and trauma will continue to leak in from other states. But because the primary benefit that Vermonters seek when allowing gay marriage is simply the effectuation of their subjective preference for marriage equality, they are very unlikely to change their regulatory outcome in response to imported harms from Maine. ${ }^{67}$ Furthermore, although Vermonters may feel that Maine's marriage protection statute decreases their enjoyment of marriage equality in Vermont, that harm is also extremely unlikely to impact their regulatory decision.

This picture contrasts sharply with the picture of objective, outcomes-based regulation, where the importation of harms changes the level of success that a regulation can achieve and therefore undermines the state's entire reason for regulating. That is, in the pollution case, if New Hampshire cannot reduce environmental harms associated with manufacturing due to externalities from Massachusetts, then it might not regulate at all. Other than the reduction of those costs, New Hampshire has little if any reason to stop its industries from polluting.

Second, consider liberty: structural liberty is generally more important for subjective regulations than for objective ones. Most obviously, voice matters more in subjective regulatory regimes because the optimality of a regulatory outcome in those regimes depends on whether it represents most citizens' preferences. Regulators will have better knowledge of those preferences if they represent fewer voters. It is also likely that the harm of tyranny and the benefit of diversity are greater for subjective regulations. The American constitutional system protects freedom of conscience well above freedom of contract. Citizens' ability to choose a regulatory regime that best captures their subjective preferences might therefore be

${ }^{66}$ See generally Maria Godoy, State By State: The Legal Battle Over Gay Marriage, NPR (Feb. 7, 2012), http://www.npr.org/2009/12/15/112448663/state-by-state-the-legal-battle-over-gay-marriage (showing that Maine has a marriage protection statute while Vermont allows gay marriage).

${ }^{67}$ This portrayal is one-sided only for the sake of simplicity. The story works just as well if we imagine harms arising in a marriage equality state flowing into a traditional marriage state. The traditional marriage state is unlikely to change its regulatory result in response to those harms. 
constitutionally more important than their ability to choose a regulatory regime that best meets their objective needs. For example, compare a homophobic citizen who moves from Vermont to Maine to take advantage of Maine's marriage protection statute to a negligent doctor who moves from Nevada to California to take advantage of California's cap on noneconomic damages in medical malpractice cases. ${ }^{68}$ Both have taken advantage of libertarian federalism, but one has done so to satisfy subjective preference while the other has done so to satisfy objective need. Regardless of one's prior views of gay marriage or medical malpractice awards, American lawyers might tend to think more kindly of the homophobe than the quack simply because the Constitution protects homophobia but not quackery. ${ }^{69}$ (Note that homophobia does not get substantive due process protection. The idea here is a general one of freedom of conscience - a First Amendment right if anything - rather than a specific substantive right under the Fifth or Fourteenth Amendment.)

Monitoring is the one structural libertarian advantage of state control that does not seem to vary based on the subjectivity or objectivity of a regulatory question. It is equally easy for a regulating class to externalize costs onto a regulated class through subjective regulation as through objective regulation, and reliable information about subjective costs is equally hard to gather as reliable information about objective costs. If anything, it might be slightly easier to figure out the voting majority's preferences than its needs because reliable polling might be slightly cheaper than reliable empirical studies.

There are two important points to make about this distinction before moving on. First, the distinction between subjective and objective regulation roughly tracksbut is more nuanced than - the Supreme Court's distinction between economic and noneconomic regulation. Most economic regulation is objective and outcomeoriented while most noneconomic regulation is subjective and expression-oriented. That said, the overlap is imperfect. The Gun-Free School Zones Act, for example, strikes me as an objective and outcomes-based rather than subjective and preferencebased statute, even though the Supreme Court in Lopez certainly was right that it is primarily noneconomic. ${ }^{70}$ Congress's goal with the GFSZA probably was not to satisfy a subjective preference for excluding guns from schools; the members seemed earnestly interested in combating bad outcomes from school shootings and school violence. In other words, if confronted with objective proof that the presence of guns in schools has no bad effects for education or criminality, the members probably would have changed their minds. As a result, the externalities described in Part II.A.2 might have a real impact on states' willingness to enact GFSZA statutes, and collective action problems might be a serious hindrance to state-based regulation. ${ }^{71}$ (In Morrison, by contrast, it seems likely that the motivation for the

${ }^{68}$ See generally Peter P. Budetti \& Teresa M. Waters, Medical Malpractice Laws in the United States, KAISER FAM. FOUND., 22 (2005), http://www.kff.org/insurance/upload/Medical-MalpracticeLaw-in-the-United-States-Report.pdf (indicating that the average damage award in Nevada is significantly higher than in California); Ethan M.J. Lieber, Medical Malpractice Reform and the Distribution of Physicians (Univ. of Chi. Dep't of Econ., Working Paper, 2012), $\mathrm{http} / / /$ home.uchicago.edu/ elieber/advselpaper.pdf (finding that negligent doctors are more likely than non-negligent doctors to move in response to changing medical malpractice laws).

${ }^{69}$ For a similar argument, see Hills, supra note 10, and Roderick M. Hills, Jr., Federalism as Westphalian Liberalism, 75 Fordham L. Rev. 769 (2006)

${ }^{70}$ See United States v. Lopez, 514 U.S. 549, 557 (1995).

${ }^{71}$ Notably, Congress responded to Lopez in 1996, less than a year after the Court's opinion, by simply adding a jurisdictional element to the statute, such that it applies only to guns that have traveled in interstate commerce (which is the vast majority of them). See Pub. L. No. 104-208, Title 
Violence Against Women Act was just the view that domestic violence is wrong. VAWA's supporters probably would not change their minds if confronted with evidence that battered women are equally productive in society-or even if confronted with evidence that they are more so.)

The second point about the subjective-objective distinction is that it is merely a generality that emerges from the cost-benefit theory; it is not the theory's ultimate meaning or content. There might, therefore, be examples of subjective regulations that should be assigned to the national government - if the liberty costs of national regulation are demonstrably smaller than the efficiency costs of state regulationand there might also be examples of objective regulations that should be assigned to the state governments. Nevertheless, cost-benefit federalism provides a better general picture than collective action federalism of when national regulation ought to be allowed.

\section{POLITICAL FEDERALISM AND JUDICIAL ADMINISTRATION}

Writing in 1954, Herbert Wechsler famously argued that the states could protect their sovereign status through their structural role in selecting national leaders and in passing national statutes. ${ }^{72}$ The political safeguards of federalism, Wechsler argued, counseled against any judicial role in reviewing federalism challenges and invalidating national laws. ${ }^{73}$ Of course, Wechsler's view has not carried the day; since the early 1990s, the Supreme Court has increased its role in federalism enforcement. ${ }^{74}$ Nevertheless, the political safeguards of federalism frequently impact national legislation in ways that are important to the cost-benefit theory. Furthermore, the cost-benefit theory aligns with Wechsler's instinct and with modern doctrinal practice insofar as it argues for a high degree of judicial deference to national legislative outcomes (though perhaps slightly less judicial deference to states' legislative outcomes). ${ }^{75}$

This Part considers the modern picture of political federalism and the limits of judicial enforcement under the cost-benefit theory. Both the states' political power and the courts' political isolation complicate the theory, at least in its application to constitutional challenges. This Part notes, first, that states often win the right to preserve liberty within national regulatory regimes and that national regulation often successfully balances efficiency and liberty within single statutory structures. Second, this Part concedes that the optimal balance between efficiency and liberty will be difficult if not impossible to assess, for courts and legislatures alike, and it argues on that basis that federalism enforcement should be left primarily to the more democratically legitimate branch: the legislature. That said, because the national government can preserve state advantages more easily than the states can capture national advantages, the judiciary might be justified in enforcing state-limiting rules, like the Dormant Commerce Clause, more strictly than nation-limiting rules.

VI, §657, 110 Stat. $3009,3009-369$ to $3009-370$ (1996). The statute has thus been in nearly continuous effect since its first enactment in 1990, notwithstanding its invalidation in Lopez.

${ }^{72}$ Herbert Wechsler, The Political Safeguards of Federalism: The Role of the States in the Composition and Selection of the National Government, 54 Colum. L. REv. 543 (1954).

${ }^{73}$ See id.

${ }^{74}$ See generally Daniel A. Farber, The Constitution's Forgotten Cover Letter: An Essay on the New Federalism and the Original Understanding, 94 Mich. L. REV. 615, 618-26 (1995) (tracing the origins of "the new federalism" - the Court's renewed assertions of authority to enforce federalism norms - from the 1970s through the Lopez decision).

${ }^{75}$ See generally Wechsler, supra note 72. 


\section{A. Political Federalism}

For the sake of simplicity, the discussion in Part II assumed that regulation must be either wholly state or wholly national. But, of course, many regulatory regimes are both. Through their constitutional power in the selection of Senators and Presidents and through their lobbying power in the National Conference of State Legislatures and National Governors Association, for example, the states frequently win concessions in national statutes and national regulations, allowing them a continuing role in regulatory regimes that Congress partially assumes. ${ }^{76}$ National statutes preserve the states' role in two ways: First, some national statutes are narrowly preemptive or non-preemptive, allowing Congress to fix externalities and collective action problems without affecting the states' internal regulatory decisions. ${ }^{77}$ Second, many national regulatory regimes take the form of "cooperative federalism," ${ }^{78}$ by which the national government sets a regulatory floor and provides national funding but relies on the state governments to implement a program that is at least as comprehensive as the national floor.

Consider first non-preemptive national law that solves externalities. Gay marriage provides an easy though controversial example of this kind of national legislation. Although marriage, including gay marriage, is primarily a state issue under modern law, the Federal Defense of Marriage Act (DOMA) ${ }^{79}$ limits the possible externalities that might arise as states begin to permit gay marriage. That is, DOMA does not preempt or otherwise interfere with states' marriage licensure regimes or their own marriage benefits rules, but it does ensure that "traditional marriage" states must neither recognize gay marriages performed in other states nor fund national marriage benefits for gay couples. ${ }^{80}$ DOMA, thus, is an example of a non-preemptive national regulation that exists solely for the purpose of alleviating collective action problems among the states, making it easier for some states to allow gay marriage without imposing costs on others and making it easier for the other states to capture the full costs and benefits of prohibiting gay marriages within their borders. The national statute thus facilitates rather than threatening libertarian federalism. ${ }^{81}$

${ }^{76}$ See generally Gillian E. Metzger, Administrative Law as the New Federalism, 57 DUKE L.J 2023 (2008). For a discussion of states' roles in selecting senators and presidents, see Wechsler, supra note 72 .

${ }^{77}$ For the proposition that preemption is worse for states and federalism than commandeering, see generally Jessica Bulman-Pozen \& Heather Gerken, Uncooperative Federalism, 118 YALE L.J. 1256 (2009)

${ }_{78}$ See generally Philip J. Weiser, Towards a Constitutional Architecture for Cooperative Federalism, 79 N.C. L. REv. 663 (2001); Hills, supra note 11.

${ }^{79}$ See Defense of Marriage Act, Pub. L. No. 104-199, 110 Stat. 2419 (1996) (codified at 1 U.S.C. $\S 7 ; 28$ U.S.C. $\S 1738$ C). Several federal court cases are currently considering the substantive and structural constitutionality of DOMA. See, e.g., Hara v. Office of Pers. Mgmt., No. 09-3134 (Fed. Cir. May 18, 2009); Torres-Barragan v. Holder, No. 10-55768 (9th Cir. May 14, 2010); Gill v. Office of Pers. Mgmt., 699 F. Supp. 2d 374 (D. Mass. 2010); Massachusetts v. U.S. Dep't of Health \& Human Servs., 698 F. Supp. 2d 234 (D. Mass. 2010); Bishop v. United States, No. 04-848 (N.D. Okla.); Dragovich v. Dep't of the Treasury, No. 10-1564, 2012 WL 253325 (N.D. Cal. Jan. 26, 2012). President Obama has decided not to defend the statute in court. See David G. Savage \& James Oliphant, Obama Administration Shifts Legal Stance on Gay Marriage, L.A. Times (Feb. 23, 2011), http://articles.latimes.com/2011/feb/23/nation/la-na-obama-gay-marriage-20110224/2 .

${ }^{80}$ See Defense of Marriage Act, Pub. L. No. 104-199, 110 Stat. 2419.

${ }^{81}$ I realize that this may be a controversial — and is certainly an atypical—view of DOMA, but its limiting effect on externalities is certainly one of its effects. 
Furthermore, even when national law includes substantive regulations that might cause doctrinal preemption when conflicts arise between state and national rules, ${ }^{82}$ those statutes can preserve a continuing state role that serves the purposes of libertarian federalism. That is, Congress frequently passes legislation that empowers national regulators to intervene when collective action problems arise but nevertheless allows state governments to continue regulating alongside the national government. The courts will read federal statutes narrowly, presuming that they are minimally preemptive, as long as the statutes do not include explicit preemption provisions and do not clearly intend to govern an entire regulatory field. This narrow preemption approach is common in the criminal law, for example, where the national government has authority to prosecute crimes that cross state lines, but the states also have authority to prosecute the same crimes, whether or not the crimes cross state lines. This structure allows the national government to pursue criminal law enforcement when no state has a complete incentive to do so-when the costs of criminality are distributed across several states. It also allows the Federal Bureau of Investigation and U.S. Department of Justice (DOJ) to take over when multiple states want to prosecute a single instance of crime - a single murder, for exampleand cannot overcome their collective action problems. But this structure also allows the states a continuing role in defining criminal behavior and enforcing criminal prohibitions, providing some structural libertarian protection within a regime that is sufficiently nationalized to fix externalities.

Indeed, a story of the complex interplay between efficiency and liberty in nonpreemptive regulatory regimes has played out recently in the case of marijuana prohibitions. National law criminalizes possession and distribution of marijuana, and the national government holds settled constitutional authority to punish intrastate instances of those crimes. ${ }^{83}$ But state law also criminalizes possession and distribution of marijuana, and states may enforce their own prohibitions without running afoul of the Supremacy Clause. ${ }^{84}$ That is, the national ban is not fully preemptive of state laws, and the states therefore have a continuing role in defining drug offenses.

When several states started revising their prohibitions to allow marijuana possession and distribution for medical purposes, ${ }^{85}$ that action put pressure on the national government to ease its enforcement efforts with respect to possession and distribution that complied with state law. Although it took a long time after the first such permissive statute passed before the national government responded, President Obama eventually announced that his administration would not enforce the federal drug statute against medical marijuana dispensaries that complied with state and local regulations. ${ }^{86}$ Even in the face of national regulation, then, the states were able

${ }^{82}$ See generally Jamelle C. Sharpe, Legislation Preemption, 53 WM. \& MARY L. REV. 163, 17580 (2011) (describing doctrinal preemption rules and generally theorizing Congress's power to set its own rules for preemption).

${ }^{83}$ See Gonzales v. Raich, 545 U.S. 1 (2005).

${ }^{84}$ Preemption rules generally flow from the Supremacy Clause. See Altria Grp. v. Good, 555 U.S. 70, 76 (2008).

${ }^{85}$ See, e.g., Compassionate Use Act of 1996, Cal. Health \& Safety Code $\S 11362.5$ (West 1996); Oregon Medical Marijuana Act, OR. Rev. StAT. ANN. $§ 475.300$ (West 1998); see also 16 Legal Medical Marijuana States and DC: Laws, Fees, and Possession Limits, ProCon.Org (Feb. 8, 2012), http://medicalmarijuana.procon.org/view.resource.php?resourceID=000881.

${ }^{86}$ See David Johnston \& Neil A. Lewis, Obama Administration to Stop Raids on Medical Marijuana Dispensers, N.Y. TIMES, Mar. 19, 2009, at A20. 
to serve their libertarian function of representing local majority preferences and regulating competitively to capture diverse regional optimalities.

In October 2011, however, DOJ announced an enforcement effort in California - one of the sixteen states with a permissive medical marijuana statute at the time (and the first to pass such a law) ${ }^{87}$ The problem was that the state seemed to be under-enforcing its own regulations against for-profit marijuana traffickers, many of which, DOJ asserted, were operating interstate. ${ }^{88}$ Surprising her promedical-marijuana constituency, the state attorney general largely acquiesced in the crackdown, but she urged DOJ to limit its efforts to trafficking organizations and to respect the state's legitimate medical marijuana industry. ${ }^{89}$ The complex interplay between state and federal regulation, then, has roughly tracked the cost-benefit theory, where the libertarian pressure for medical marijuana urged the national government to minimize its role in the regime, but the inefficiencies in state regulation of an interstate market compelled the national government to reassert itself-at least somewhat.

More common than non-preemptive or narrowly preemptive national statutes, however, are national regulations that rely on state administration-"cooperative federalism" programs. ${ }^{90}$ Cooperative federalism self-consciously preserves the states' structural advantages, at least in part. Because cooperative federalism has received significant scholarly attention as a strategy for effecting a federalist balance, ${ }^{91}$ I will spend less time discussing its application to cost-benefit federalism than I did for preemption. But just to concretize the point here, let's consider the Medicaid example and how it works for cost-benefit federalism. The Medicaid statute provides national funding and guidelines for public health insurance programs, but the programs themselves are structured and administered by the states. ${ }^{92}$ The states thus have a crucial role in defining Medicaid entitlements, which helps to preserve the state advantages of competition, diversity, voice, and exit in the regime of public insurance for the poor. Meanwhile, though, national taxpayers fund a portion of each state's Medicaid program to offset externalities from mobile Medicaid beneficiaries (externalities that would result in a classic race to the bottom in the absence of national offsets ${ }^{93}$ ). The national government also sets guidelines for qualifying Medicaid programs, setting a federal floor for the program to ensure that states do not misuse the national funding or engage in a race to the bottom with national complicity. The Department of Health and Human Services (HHS) enforces

\footnotetext{
${ }^{87}$ See generally 16 Legal Medical Marijuana States and DC, supra note 85

${ }^{88}$ See John Hoeffel, Obama Shifts to a Hard Line on Pot Sales: For-Profit Medical Marijuana Sales Are Target of Wide-Ranging Crackdown in State, L.A. TimeS, Oct. 8, 2011, at 1.

${ }^{89}$ See Kamala Harris Defends Medical Marijuana: California Attorney General Asks Federal Government to Ease Enforcement, HufFINGTON POST (Oct. 20, 2011, 9:55 PM), http://www.huffingtonpost.com/2011/10/21/kamala-harris-defends-medicalmarijuana_n_1023310.html.

${ }^{90}$ See , e.g., Elizabeth Weeks Leonard, State Constitutionalism and the Right to Health Care, 12 U. PA. J. CONST. L. 1325, 1338 (2010) (defining cooperative federalism programs, such as Medicare and the State Children's Health Insurance Program (SCHIP), as ones where states "receive a percentage-on-the-dollar match from the federal government for every state dollar spent"); Susan Rose-Ackerman, Cooperative Federalism and Co-optation, 92 YALE L.J. 1344 (1983) (arguing for cooperative federalism through federal grants and monies); see also Hills, supra note 11.

${ }^{91}$ See generally Bulman-Pozen \& Gerken, supra note 77.

${ }^{2}$ See generally Abigail R. Moncrieff, Comment, Payments to Medicaid Doctors: Interpreting the "Equal Access" Provision, 73 U. CHI. L. Rev. 673, 675-76 (2006) (describing the basic structure of Medicaid's cooperative federalism).

${ }_{93}^{3}$ See Moncrieff, supra note 55, at 2350-51.
} 
that floor by reviewing state plans before they go into effect. ${ }^{94}$ The Medicaid program thus strikes a balance between state and national power that roughly tracks the relative advantages of the two levels of government. The states are responsible for the design and daily administration of the program so that they can be responsive to local needs and preferences, and the national government attempts to cure interstate externalities through financial transfers, regulatory floor-setting, and administrative oversight. ${ }^{95}$

In short, the states' political power frequently works to limit the scope of national statutes. Many such statutes preserve significant opportunities for state regulation. More importantly, the states' role under these narrow and cooperative statutes works to preserve the advantages of libertarian federalism. ${ }^{96}$ Even in regimes like marijuana regulation, where a sweeping national statute with unambiguous constitutional backing seems to present an insuperable barrier, states can assert their interests and create opportunities for structural libertarianism.

Importantly, the political balance of power occurs far less frequently in reverse. Although they are capable of doing so, the states rarely enter into regulatory compacts in order to capture the efficiency advantages of national regulation. One could imagine, for example, that Medicaid could work through a series of regional compacts that would cover the insurance needs of regional rather than state or national populations, or that California could enter into a compact with its neighbors to prevent trafficking in recreational marijuana. But that kind of cooperative statebased regulation rarely happens.

In the end, then, when courts are reviewing national statutes for constitutional validity, the statutes' preservation of political opportunities for libertarian federalism should be relevant to the analysis. When courts are reviewing state statutes for constitutional validity under the Dormant Commerce Clause, however, the possibility for coordination among states should be less relevant. National action is much more likely to preserve the advantages of libertarian federalism than state action is to capture the advantages of collective action federalism.

\section{B. JUDICIAL ADMINISTRATION}

The second complicating factor for cost-benefit federalism is the difficulty of ascertaining optimality. This problem is not at all unique to cost-benefit federalism - it is pervasive in regulatory and constitutional decision-making. ${ }^{97}$ But the problem raises an institutional competence issue for the cost-benefit theory. If the test for constitutional federalism depends on assessing the optimal balance between liberty and efficiency, how can courts apply that test given their imperfect information about regulatory and structural costs and benefits?

${ }^{94}$ See Review of State Plan Material, 42 C.F.R. $§ 430.14$ (2012) (designating regional staff to review state Medicaid plans and amendments).

${ }^{95}$ Medicaid has not been the most successful cooperative federalism program. See generally Moncrieff, supra note 55. Other such programs, particularly in telecommunications and environmental law, have done better. See, e.g., Philip J. Weiser, Chevron, Cooperative Federalism, and Telecommunications Reform, 52 VAND. L. REV. 1 (1999); Alice Kaswan, A Cooperative Federalism Proposal for Climate Change Legislation: The Value of State Autonomy in a Federal System, 85 DENV. U. L. REV. 791 (2008).

${ }^{96}$ See, e.g., Bulman-Pozen \& Gerken, supra note 77; Metzger, supra note 76.

${ }^{97}$ Cass R. Sunstein, Humanizing Cost Benefit Analysis, Remarks Prepared for American University's Washington College of Law Administrative Law Review Conference (Feb. 17, 2010), available at http://www.whitehouse.gov/omb/oira_speech_02172010 (describing the use of cost-benefit analysis by the Office of Information and Regulatory Affairs, which oversees all federal regulations). 
My answer-theoretically unsatisfying though it may be - is that the judiciary should review for extreme violations of cost-benefit federalism but should largely defer to Congress. The barrier that prevents first-best application of cost-benefit federalism is an informational barrier-the inability of any governmental body to discern the need for structural libertarianism, to assess the risk of tyranny, to calculate the magnitude of externalities, to ascertain the optimal level of regulatory intervention, etc. In short, the libertarian costs of nationalization and the efficiency costs of diffusion are simply impossible to estimate. In considering the proper scope of judicial review, then, the question is not whether or how the courts can figure out cost-benefit optimality. They can't. The question, instead, is whether Congress or the courts will generally do better at figuring out that optimality. Based on their relative structural competencies, the obvious answer is that Congress will generally do better than the Court.

First, simply by virtue of comprising a representative body subject to regular elections, members of Congress have a stronger structural incentive than Supreme Court Justices to understand constituents' needs and preferences. Members have strong electoral incentives to gather information about the true costs and benefits of a regulatory question while the politically insulated judiciary has little incentive to engage in more than a superficial or academic assessment of those costs and benefits.

Second, congressional decision-making has procedural advantages for information gathering. When the Supreme Court considers a case, only a limited population of interested entities will have access to the proceedings, and many of them will have access only through the imperfect mechanism of 9000-word amicus briefs. ${ }^{98}$ When Congress regulates, however, there are no rules limiting interested parties' access to the decision-makers, except prohibitions on bribery. ${ }^{99}$ Unlike courts and other adjudicative bodies, legislatures are actively encouraged to engage in ex parte communications, gathering as much information as possible about the overall regulatory picture they are confronting.

Finally, Congress is responsively federalist in a way that the Supreme Court is not. Because the states have equal representation in the Senate and because the Senate's composition changes partially every two years and fully every six, Congress's structural incorporation of federalist information is regularly updated. Congress therefore responds structurally to changing needs and preferences if new regional majorities form and want libertarian protection through diffusion of authority or if interstate externalities emerge and require collective action through centralization of authority. Either of those emerging needs will cause the Senate's composition to change (or its members' opinions to change), assuming that voters in the affected states behave rationally. The Supreme Court, by contrast, is far less responsive. The Justices are appointed with advice and consent of the Senate- not the House - and therefore reflect federalism somewhat at the time of their appointment. But because they hold life tenure unless impeached, the Supreme Court's structural federalism will be much slower to catch up to changing needs and preferences in the states.

In short, Congress's greater democratic legitimacy - its electoral incentives, its procedural inclusiveness, and its structural responsiveness-give it greater institutional competence to assess optimality in federalism. Congress will not reach

\footnotetext{
${ }^{98}$ SUP. CT. R. 37.

${ }^{99}$ See 18 U.S.C. $§ 201$ (2006) (prohibiting bribery of public officials and witnesses).
} 
the perfect result in all cases because it will have imperfect information in all cases, but its claim to legitimacy in the effort is greater than the Supreme Court's.

All of that said, the Supreme Court can be useful in policing the extremes. Notwithstanding the Senate's structural protection of state interests, national regulation still requires only a majority of state majorities to acquiesce. It is therefore possible that the national government will take power in cases in which state or regional majorities with intense preferences would benefit more from state power than the national majority would benefit from national power. When that kind of case transparently occurs, the Supreme Court can usefully intervene. Of course, the Court might well make mistakes, deviating from first-best optimality and invalidating laws that should stand. But as long as the Court continues to apply a relatively deferential standard of review (as it currently does), the mistakes should be few and minor.

As a final note, it is worth repeating that cost-benefit theory suggests one generalization for when national power should be allowed - the subjective-objective distinction-and that distinction is one that the Supreme Court probably can administer fairly easily. Legislators' motivations for regulating might be somewhat obscure and certainly will be harder for the Court to assess than for the legislators themselves to understand. But in extreme cases in which legislators justify their regulations solely in subjective terms (and in which collective action problems seem minor), the Court can usefully send the regime back to the states. ${ }^{100}$

\section{COST-BENEFIT FEDERALISM AND OBAMACARE'S INDIVIDUAL MANDATE}

What does the cost-benefit theory suggest about the Obamacare litigation and the constitutionality of the individual mandate? Whether analyzed under the commerce power or the taxing power, the question for cost-benefit federalism is whether the individual mandate produces enough efficiency gains to offset its libertarian losses. That question, though, should also take account of the statute's political federalism - its preservation of state power within the national regulatory regime. This Part ${ }^{101}$ argues that the litigants and commentators in the Obamacare case have exaggerated all three of those factors. Because the individual mandate preserves far more state power than commentators have recognized, the provision gains much less for efficiency than collective action federalists have asserted and costs much less for liberty than libertarian federalists have asserted. Overall, though, the statute strikes a rational federalist balance and deserves the Supreme Court's deference.

${ }^{100}$ This rule for federalism also makes some sense of the Supreme Court's choice to scrutinize legislative findings in Commerce Clause cases. See United States v. Lopez, 514 U.S. 549, 562 (1995).

${ }^{101}$ Throughout this Part, I will borrow heavily from two amicus briefs that my students and I coauthored for the Supreme Court litigation, under the supervision of attorneys Andrew Fischer and Kevin Outterson. See Brief of Amici Curiae Jewish Alliance for Law \& Social Action (JALSA), Jewish Council on Urban Affairs (JCUA), Jewish Social Policy Action Network (JSPAN), New England Jewish Labor Committee (JLC), \& Professor Abigail R. Moncrieff in Support of Petitioners on the Individual Liberty Implications of the Minimum Coverage Provision, Dep't of Health and Human Servs. v. Florida, No. 11-398 (U.S. Jan. 13, 2012), 2012 WL 160243 [hereinafter JALSA Brief]; Brief Amici Curiae of Prescription Policy Choices, Professors of Law, \& Professors of Health Policy in Support of Petitioners on the Minimum Coverage Provision, Dep't of Health \& Human Servs. v. Florida, No. 11-398 (U.S. Jan. 13, 2012), 2012 WL 160229 [hereinafter PPC Brief]. I thank Andrew and Kevin, as well as students David Arnold, Julia Mirabella, Zoë Sajor, Rachel Smit, Kyle Thomson, Hao Wang, and Emily Westfall, for their contributions to this research. 


\section{A. STATE POWER Under OBAMACARE (AND BEFORE)}

Most of the exaggeration of Obamacare's federalism derives from a misunderstanding of the degree to which Obamacare centralizes regulatory authority. ${ }^{102}$ Perhaps because the version of healthcare reform that emerged from Congress was the Senate's instead of the House's ${ }^{103}$ the statute preserves much of the preexisting state authority over insurance regulation, and it charges the states with administering many of the statute's new programs and rules. Obamacare thus preserves significant opportunities for interstate competition and diversification through both of the avenues described above. It is incompletely preemptive, and it incorporates state administration through cooperative federalism.

First, although Obamacare obviously includes many new national insurance regulations - the prohibitions on preexisting condition exclusions, contract rescissions, benefit caps, medical underwriting, etc. ${ }^{104}$-it preserves some of the states' most important regulatory tools-their exclusive power over insurance licensure,${ }^{105}$ their corresponding immunity from federal antitrust enforcement, ${ }^{106}$ and their traditional power to review insurance rates. ${ }^{107}$ Under Obamacare, thus, a state may refuse to license any given insurance company to write and sell policies within its borders, even if the insurance company complies fully with national regulations. The states thus possess - and retain under Obamacare - an absolute power of exclusion that they can use to control the health insurance products available to their citizens. Moreover, after extensive state lobbying during the passage of the ACA, Congress opted not to repeal the McCarran-Ferguson Act, ${ }^{108}$ which continues to exempt insurance from federal antitrust regulations. ${ }^{109}$ Any state that chooses to do so may create an insurance monopoly or oligopoly within its borders without fear of federal intervention. Obamacare is thus a classic example of narrowly preemptive national floor-setting. The states obviously cannot make it legally permissible for insurance companies to violate Obamacare's substantive regulations, but they may impose additional requirements on insurance companies and may refuse to allow noncompliant insurance products to be sold within their borders.

Second, even with respect to the new national insurance regulations (the new national floor), Obamacare places primary enforcement authority with the states. ${ }^{110}$ The insurance regulations, thus, resemble the criminal law situation described above. Because the states retain primary authority to oversee their own insurance markets,

102 The Eleventh Circuit, for example, merely asserted without citation or elaboration "that the individual mandate supersedes a multitude of the states' policy choices in these key areas of traditional state concern." Florida ex rel. Att'y Gen. v. U.S. Dep't of Health \& Human Servs., 648 F.3d 1235, 1306 (11th Cir. 2011), cert. granted sub nom. Nat'l Fed'n of Indep. Bus. v. Sebelius, 132 S. Ct. 603 (2011) (mem.), and cert. granted, 132 S. Ct. 604 (2011) (No. 11-398) (mem.) (argued Mar. 26-27, 2012), and cert. granted in part, 132 S. Ct. 604 (2011) (No. 11-400) (mem.) (argued Mar. 28, 2012).

${ }^{103}$ Compare Patient Protection and Affordable Care Act of 2010, H.R. 3590, 111 th Cong. (2010) (Senate version of the bill), with America's Affordable Health Choices Act of 2009, H.R. 3200 (2009), Title II, Subtitle A, available at http://www.opencongress.org/bill/111-h3200/text.

${ }^{104}$ See 42 U.S.C.A. § 300gg-1-1-19a (2012).

${ }^{105}$ Christopher C. Jennings \& Katherine J. Hayes, Health Insurance Reform and the Tensions of Federalism, 362 NEW ENG. J. MED. 2244, 2245 (2010) (noting that states will continue licensing insurers).

${ }^{106}$ See McCarran-Ferguson Act, 15 U.S.C. $\S \S 1011-1015$ (2006).

${ }^{107} 42$ U.S.C.A. \$ 300 gg-94 (West 2012).

108 U.S.C. $\$ \S 1011-1015$.

109 See Jonathan Dinan, Shaping Health Reform: State Government Influence in the Patient Protection and Affordable Care Act, 41 PuBlius 395, 399, 412-13 (2011).

${ }^{110} 42$ U.S.C.A. \$ $300 \mathrm{gg}-22$. 
consistently, of course, with the national substantive law, they retain a lever that they can use to influence national policy-making. As in the criminal law context, the national government has the power to step in if the states fail, but the states' primary enforcement power preserves some advantages of libertarian federalism.

Third, Obamacare also engages the states in the administration of many of the statute's regulatory innovations, following the standard model of cooperative federalism. Even with respect to Congress's new programs, therefore, the states retain a role in shaping policy. The "American Health Benefit Exchanges" are the best-known examples of this cooperative federalist structure in Obamacare; ${ }^{111}$ the statute charges the states with implementing the exchanges and provides tremendous flexibility for state diversification. ${ }^{112}$ But the statute also provides for "state innovation waivers" that allow for cooperative federalism in nearly all aspects of the Obamacare regulatory world. ${ }^{113}$ Indeed, the waiver provision empowers HHS to excuse individual states from most of Obamacare's regulatory requirements, as long as the state comes up with a different way to achieve comparable results.

Finally, it is important to note the limited scope of Obamacare's "national takeover" relative to the status quo ante. The pre-Obamacare world was not one of state exclusivity or even of clear state primacy in health insurance regulation. All of our various insurance markets were already subject to some national regulation before Obamacare was even conceived: regulation for everyone over the age of sixty-five was exclusively national under Medicare. ${ }^{114}$ Regulation for many people living just above, at, or under the Federal Poverty Line was significantly national under Medicaid. ${ }^{115}$ Regulation for employer-sponsored insurance through selfinsured employers was exclusively national under the Employee Retirement Income Security Act of 1974 (ERISA). ${ }^{116}$ And regulation for individual and small-group coverage was partly national under the Health Insurance Portability and Accountability Act of $1996 .{ }^{117}$ The only sectors of health insurance that were not subject to national regulation before Obamacare were fully insured employersponsored coverage and self-insured individual coverage (i.e., the uninsured). ${ }^{118}$ Those two markets are the only two that Obamacare "took over" from a status quo ante of primary state control.

\footnotetext{
${ }^{111} I d . \S 18031$

${ }^{112}$ See generally Jon Kingsdale \& John Bertko, Insurance Exchanges Under Health Reform: Six Design Issues for the States, 29 HeAlth AFF. 1158 (2010); State Actions to Implement Health Exchanges, NAT'L CONF. OF STATE LEgS. (Feb. 25, 2011), http://www.ncsl.org/issuesresearch/health/state-actions-to-implement-the-health-benefit-exch.aspx (demonstrating that the states are already taking advantage of the statute's flexibility and pursuing divergent strategies for implementing exchanges).

11342 U.S.C.A. § 18052; see also Press Release, Office of the Press Sec'y, Fact Sheet: The Affordable Care Act: Supporting Innovation, Empowering States (Feb. 28, 2011), available at http://www.whitehouse.gov/the-press-office/2011/02/28/fact-sheet-affordable-care-act- supportinginnovation-empowering-states.

${ }^{114}$ See 42 U.S.C. $\$ 1395$ (2006).

${ }^{115}$ See Id. $\$ 1396$.

${ }^{116}$ Pub. L. 93-406, 88 Stat. 829 (1974).

${ }^{117}$ Pub. L. 104-191, 110 Stat. 1936 (1996).

118 See generally Russell Korobkin, The Battle of Self-Insured Health Plans, or "One Good Loophole Deserves Another," 5 YAle J. HeAlth POL'Y L. \& ETHICS 89, 92-105 (2005) (explaining ERISA preemption).
} 


\section{B. OBAMACARE AND REGULATORY EFFICIENCY}

With that picture of Obamacare's federalism, what can we say about the statute's gains for regulatory efficiency? Does it alleviate or prevent problematic interstate externalities in the relevant markets? The answer is that it undoubtedly does, but the individual mandate is less necessary and less effective than collective action federalists have asserted. Indeed, most of the statute's corrections of interstate collective action problems come from the insurance regulations, not the mandate. ${ }^{119}$

The standard account for why the individual mandate is necessary is that it solves adverse selection. Once Obamacare's insurance reforms go into effect, the argument goes, insurance companies will no longer be allowed to deny coverage to patients who wait until they are sick to buy insurance, allowing individuals to freeride on the system by refusing to pay into insurance until they need to take out of it. ${ }^{120}$ The individual mandate addresses that problem by imposing a financial incentive to encourage regular participation in insurance pools, regardless of one's current health. ${ }^{121}$

This story is undoubtedly right, but it is a story of collective action problems among individuals, not collective action problems among states. The federalism question ought to be whether the state governments are separately incompetent to solve this market-based problem of adverse selection. With respect to the insurance market regulations (the prohibitions on preexisting condition exclusions and such), the answer is that the states suffer from significant externalities that render them incapable of regulating efficiently. Before Obamacare, the states that attempted to ban the same insurance practices and to impose community rating lost insurance companies to other, laxer states. ${ }^{122}$ Furthermore, a rational state might under-impose and under-enforce such requirements out of a concern that generous insurance laws would attract sick and costly residents to their jurisdictions. The insurance market reforms, thus, need to be national.

But no one is challenging those regulations. Indeed, under the Supreme Court's decision in United States v. South-Eastern Underwriters, ${ }^{123}$ there is no doubt that Congress has constitutional authority to regulate the contents and practices of any insurance contract bought or sold in the United States. The only question in the Obamacare litigation is whether the additional incentive for individuals to maintain insurance coverage - the "Minimum Essential Coverage Provision"124 or "individual mandate"-is constitutionally permissible.

If that provision is, as the government has primarily argued, an attempt to solve the adverse selection problems that will arise from Obamacare's insurance regulations, then it probably does not need to be a national regulation. National regulation is necessary when an individual state's incentive to regulate is distorted relative to the collective, national optimum. Once Obamacare's unquestionably

${ }^{119}$ Compare 42 U.S.C.A. § 300gg-1-19a (West 2012) (insurance regulations), with 26 U.S.C.A. $\S 5000 \mathrm{~A}$ (West 2012) (individual mandate).

${ }_{120}$ See generally Siegel, supra note 4. See also Brief for Petitioners (Minimum Coverage Provision), Dep't of Health \& Human Servs. v. Florida, No. 11-398 (U.S. Mar. 7, 2012).

${ }^{121}$ See 26 U.S.C.A. \$ 5000A.

${ }^{122}$ See Conrad F. Meier, Destroying Insurance Markets: How Guaranteed Issue and Community Rating Destroyed the Individual Health Insurance Market in Eight States (Council for Affordable Health Ins. \& Heartland Inst. eds., 2005), available at http://www.cahi.org/cahi_contents/resources/pdf/destroyinginsmrkts05.pdf.

123322 U.S. 533 (1944).

124 ACA, Pub. L. No. 111-148, § 1501 (2010), amended by Health Care and Education Reconciliation Act of 2010, Pub. L. No. 111-152, 124 Stat. 1029 (codified in 26 U.S.C.A. § 5000A). 
constitutional insurance regulations become effective nationwide, the states' incentives to fix adverse selection within their borders will align with the national optimum. Any state that fails to impose an individual mandate or otherwise to solve adverse selection will lose insurers to regulating states. Good insurance companies will refuse to do business in states that refuse to require individual insurance coverage. That is, the externality of insurance companies moving from nonregulating states to regulating states will push the states towards (not away from) the presumed national optimum of imposing an individual mandate.

Of course, if one state refuses to do anything about adverse selection and loses its insurers to competing states, that state's uninsured and underinsured populations will impose some costs on other states. Those populations will be sicker than the average American and will therefore consume more healthcare than average when they travel to other states, draining the other states' healthcare systems. Self-insured individuals will also probably experience worse health outcomes later in life, imposing costs on other states through national Medicare taxes. ${ }^{125}$ We can also imagine that at least one insurance company will bravely stay in the holdout state and will simply charge higher rates for insurance there, and some of that insurer's higher costs might spill over into other states through the insurance company's national financial structure. There will, therefore, be some interstate externalities that will allow the holdout state to avoid the full cost of its refusal to impose a mandate. All of those avoided costs, though, will likely pale in comparison to the unavoidable cost of losing good insurers.

Furthermore, because insurance pools remain state-specific after Obamacare (because the exchanges are state-run) and because the states retain many of their traditional powers over insurance regulation, the states that do mandate coverage will be able to combat adverse selection-related externalities from the states that do not mandate coverage. Imagine, for example, that Aetna chooses to continue writing and selling policies in a state that refuses to pass an individual mandate. The adverse selection costs that Aetna incurs in the non-regulating state will not flow naturally to the regulating states through the insurance pool because the risk pools themselves are state segregated. Aetna might nevertheless try to offset the costs of selling insurance in a non-regulating state, at least in part, by raising its prices in states with mandates. But the regulating states have authority to prevent Aetna from raising rates within their borders. Because they retain power over rate-setting, they can require Aetna to charge the minimum premium necessary to cover the costs of insuring their own residents. Of course, the non-regulating states might create risks for Aetna's overall solvency - a risk that will not be state-specific-but the probability of problems arising from that externality is likely quite small. If selling insurance in a mandate-free state starts to threaten Aetna's solvency, Aetna will stop selling insurance in that state. ${ }^{126}$

In the end, then, although the insurance regulations undoubtedly improve regulatory efficiency and ought to be national and although the individual mandate will cause some externalities (as all regulations do), the individual mandate does not clearly require national uniformity. The states will need to figure out a way to address adverse selection once the insurance reforms go into effect. Perhaps, if structural libertarian costs of nationalization are significant, the states ought to be

${ }^{125}$ See generally Abigail R. Moncrieff, Federalization Snowballs: The Need for National Action in Medical Malpractice Reform, 109 Colum. L. REV. 844 (2009) (describing the externalization problems that arise from federal spending programs like Medicare and Medicaid).

${ }^{126} C f$. Siegel, supra note 4. 
permitted greater autonomy to design a solution than Obamacare's waiver provision allows.

All of that said, adverse selection is not the only reason to have an individual mandate, and the other justification for the provision more clearly benefits from national implementation. The other reason that Congress passed the mandate was to eliminate the market for self-insured healthcare transactions-for healthcare purchased at the point-of-service without third-party insurance-by shifting all patients into the more-efficient substitute market for healthcare transactions purchased with third-party insurance. ${ }^{127}$ The market for self-insured healthcare is an interstate commercial market, and the elimination of that market-like the elimination of the market for recreational marijuana ${ }^{128}$ - probably requires national action. The problem is that no state has a full incentive to prosecute individuals for failure to purchase insurance if many of their inefficient healthcare transactions will occur in other states.

This argument, though stronger in my view than the adverse selection argument, is also somewhat overblown in the literature and in the briefs. ${ }^{129}$ In their persistent references to inefficient emergency room care and to medical bankruptcies in the United States, the individual mandate's proponents exaggerate the extent to which a state can avoid the costs of its self-insured citizens' inefficient healthcare transactions. An individual who fails to save enough for needed medical care and then consumes medical care anyway imposes significant costs on her home economy. Emergency rooms are required to provide treatment regardless of the patient's ability to pay, but they are not required to provide that treatment for free. ${ }^{130}$ Even a self-insured patient who travels to a different state to consume uncompensated emergency room care thus carries the cost of her choice home in the form of a hefty bill. If she takes advantage of federal bankruptcy protections to avoid that bill, she and her home economy still suffer from her debt and divestment of assets.

As in the adverse selection case and as in all regulatory cases, there are undoubtedly interstate externalities associated with the market for self-insured healthcare transactions. The case for national action and regulatory efficiency, however, seems somewhat weaker than the collective action federalists have made it out to be. The statute's efficiency gains will be less dramatic than collective action federalists have asserted.

\section{OBAMACARE AND INDIVIDUAL LIBERTY}

What about the liberty costs of the individual mandate? Does Obamacare threaten structural liberty in a way that matters for regional majorities or for government accountability? Although the statute obviously sets the individual

\footnotetext{
${ }^{127}$ Congress asserted in two findings that the individual mandate would "increase the number and share of Americans who are insured," 42 U.S.C.A. § 18091(a)(2)(C) (West 2012), and would achieve "near-universal coverage," $i d . \S 18091(\mathrm{a})(2)(\mathrm{D})$. The next finding noted that "[t]he economy loses up to $\$ 207$ [billion] a year because of the poorer health and shorter lifespan of the uninsured" and that near-universal coverage "will significantly reduce this economic cost." Id. § 18091(a)(2)(E). Even without the explicit acknowledgement in $\S 18091(\mathrm{a})(2)(\mathrm{E})$ that Congress's goal is to eliminate selfinsurance, the stated goal of near-universal coverage in $\S 18091$ (a)(2)(C)-(D) supports the notion that Congress sought to eliminate the self-insured market.

${ }^{128}$ See Gonzales v. Raich, 545 U.S. 1 (2005).

${ }^{129}$ See PPC Brief, supra note 101.

${ }^{130}$ See Emergency Medical Treatment and Active Labor Act (EMTALA), 42 U.S.C. § 1395dd
} (2006) 
mandate as a default rule for all states and although some state majorities have vociferously opposed that default rule through their state attorneys general, the statute's libertarian costs are much less severe than the litigants and commentators have made them out to be.

The most important point here is that the individual mandate does not, contrary to the Eleventh Circuit's characterization, ${ }^{131}$ require individuals to purchase health insurance. It is instead merely a requirement that all individuals contribute some money to the American healthcare infrastructure, either by paying into a private insurance pool or by making an equivalent or lesser payment to the national fisc. ${ }^{132}$ The penalty for failure to carry insurance coverage is defined as a "shared responsibility payment," and it is statutorily calibrated to the average price of the least-comprehensive level of private insurance. ${ }^{133}$ Individuals who choose to give their money to the government instead of giving it to an insurance pool will face no financial penalty for their choice. They will simply forego the insurance coverage that they could have purchased with the same money. In this sense, then, the individual mandate is functionally indistinguishable from an ordinary tax. ${ }^{134}$

The question, then, is whether state power has significant libertarian advantages for simple taxation - or, more precisely, for targeted taxation intended to support a discrete private industry. As there are in all regulatory regimes, there are undoubtedly some structural libertarian benefits to leaving this kind of taxation to the states. Some individuals apparently feel strongly that they should not be required to support the healthcare infrastructure or to pay for others' access to needed medical services. Those individuals will have better structural protection if the states are allowed to diverge in their approaches to healthcare financing without the national restrictions and oversight that come with Obamacare's waiver provision. Individuals who strongly oppose redistributive policy in healthcare would have better opportunities for diversity, voice, and exit if the states were in charge in this case, just as they would if the states were in charge in any given case.

Furthermore, there is a reasonable chance that the individual mandate arose from something like a factional or interest-group-oriented legislative process. The mandate was essentially the price the insurance industry exacted for acquiescing in Obamacare's insurance market reforms. The mandate might, therefore, represent an externality from a ruling class of insurance companies onto an under-represented minority population of uninsured Americans. Those uninsured Americans could gain better representation for their views and perhaps better structural protection against industry-driven legislation (through interstate competition as well as diversity, voice, and exit) if the states were in charge.

${ }^{131}$ See Florida ex rel. Att'y Gen. v. U.S. Dep't of Health \& Human Servs., 648 F.3d 1235, 129192 (11th Cir. 2011), cert. granted sub nom. Nat'l Fed'n of Indep. Bus. v. Sebelius, 132 S. Ct. 603 (2011) (mem.), and cert. granted, 132 S. Ct. 604 (2011) (No. 11-398) (mem.) (argued Mar. 26-27, 2012), and cert. granted in part, 132 S. Ct. 604 (2011) (No. 11-400) (mem.) (argued Mar. 28, 2012) ("Individuals subjected to this economic mandate have not made a voluntary choice to enter the stream of commerce, but instead are having that choice imposed upon them by the federal government."); id. at 1328 ("This economic mandate represents a wholly novel and potentially unbounded assertion of congressional authority: the ability to compel Americans to buy an expensive health insurance product they have elected not to buy .....").

${ }^{132}$ See generally JALSA Brief, supra note 101. See also 26 U.S.C.A. $§ 5000$ A(b) (West 2012); id. $\S 5000 \mathrm{~A}(\mathrm{c})(1)$ (capping possible penalties at the cost of an average private plan).

13326 U.S.C.A. $\$ 5000 \mathrm{~A}(\mathrm{~b})$

${ }^{134}$ For lengthier analysis of the analogy between the mandate and a tax, including rebuttals of some arguable distinctions between the two, see JALSA Brief, supra note 101, at 11-22. 
Beyond these general libertarian costs, however, there is nothing particularly troubling about the individual mandate. It is simply a tax. That said, the strongest objections to Obamacare do seem to center on subjective preferences rather than objective needs. The voters who oppose the mandate do not seem to object merely to the financial cost of buying insurance coverage; they seem opposed to the principle of governmental insurance mandates. The problem, though, is that their subjective opposition is based on a faulty characterization of the law's effect. Obamacare does not, in fact, force individual Americans to buy private insurance policies or otherwise to "enter the stream of commerce" 135 _except insofar as all taxes require Americans to support commerce. Of course, some of the bill's opponents might object generally to taxation and might therefore seek libertarian federalism so that they can live in low-tax states. But if that libertarian cost of nationalization were sufficient to support invalidation under Article I, then no national law should be allowed. All such laws require financial support, which requires national taxation.

In short, the libertarian costs from the individual mandate are non-zero, but they are not nearly as high as the law's opponents believe. The mandate imposes no more on freedom than any ordinary tax, and although state power certainly provides libertarian advantages for taxation, there is no unique or particularly compelling need for state power in this regime.

\section{OBamacare AND Rational BaSis REviEw}

Of the three preceding subsections, perhaps the most important for judicial review under Article I-and the least appreciated and least discussed aspect of Obamacare in the litigation briefing so far-is the first subsection, on Obamacare's many preservations of state power. To the extent that Obamacare requires individuals to buy insurance, it allows states significant authority to control the kinds of insurance available for compliance with that requirement. Indeed, HHS has decided that it will not even exercise its statutory authority to define the minimum benefits package required, leaving most benefits regulation to the states. ${ }^{136}$ Although, as this Part has demonstrated, there are arguments to be made for both the efficiency benefits and the libertarian costs of the Obamacare statute, the most compelling point under rational basis review is that Congress struck a reasonable balance between national and state power. The national government did not monopolize either insurance or healthcare regulation, nor did it allow states to monopolize either regulatory regime. Given the impossibility of determining what the optimal federalist balance is for these regimes, the duly enacted and democratically legitimate Obamacare statute deserves the Supreme Court's deference.

\section{CONCLUSION}

Both of the extreme visions of federalism that have emerged in the Obamacare litigation rest on sound premises, but either theory taken alone would argue for the end of federalism. The first-best theory of American federalism would optimize the balance between the national government's efficiency advantages and the state

\footnotetext{
${ }^{135}$ See Florida ex rel. Att'y Gen., 648 F.3d at 1291-92.

${ }^{136}$ Robert Pear, Health Care Law Will Let States Tailor Benefits, N.Y. TIMES, Dec. 16, 2011, at A1, available at http://www.nytimes.com/2011/12/17/health/policy/health-care-law-to-allow-statesto-pick-benefits.html?_r=2.
} 
governments' libertarian advantages. It would seek the optimal cost-benefit balance between state and national governance. Because that optimal balance is impossible to discern, however, and because Congress is structurally better situated to gather the imperfect information that exists about regulatory costs and benefits, courts engaged in constitutional review should largely defer to legislative decisions.

In the Obamacare litigation, all of the factors that are relevant to cost-benefit federalism have been largely overblown. The individual mandate does not create as many efficiency benefits as collective action federalists claim; it does not create as many libertarian costs as libertarian federalists claim; and it generally does not nationalize healthcare or health insurance policy as much as the litigants and commentators claim. It is, at minimum, a moderate and rational-if not entirely optimal-federal statute that creates some efficiencies without sacrificing too much liberty. The Court therefore ought to defer to Congress's rational judgment and uphold the statute. 